Check for updates

Cite this: RSC Adv., 2019, 9, 30989

Received 27th March 2019

Accepted 7th September 2019

DOI: 10.1039/c9ra02327e

rsc.li/rsc-advances

\section{The effect of oxidant species on direct, non-syngas conversion of methane to methanol over an $\mathrm{FePO}_{4}$ catalyst material $\uparrow$}

\author{
Venkata D. B. C. Dasireddy, (D) *a Darko Hanzel, ${ }^{\text {b }}$ Krish Bharuth-Ram ${ }^{\text {cd }}$ \\ and Blaž Likozara
}

The effect of the phase transformation of $\mathrm{FePO}_{4}$ catalyst material from the tridymite-like (tdm) $\mathrm{FePO}_{4}$ to the $\alpha$-domain $\left(\alpha-\mathrm{Fe}_{3}\left(\mathrm{P}_{2} \mathrm{O}_{7}\right)_{2}\right)$ during the direct selective oxidation of methane to methanol was studied using oxidant species $\mathrm{O}_{2}, \mathrm{H}_{2} \mathrm{O}$ and $\mathrm{N}_{2} \mathrm{O}$. The main reaction products were $\mathrm{CH}_{3} \mathrm{OH}$, carbon dioxide and carbon monoxide, whereas formaldehyde was produced in rather minute amounts. Results showed that the single-step non-syngas activation of $\mathrm{CH}_{4}$ to oxygenate(s) on a solid $\mathrm{FePO}_{4}$ phase-specific catalyst was influenced by the nature of the oxidizer used for the $\mathrm{CH}_{4}$ turnover. Fresh and activated $\mathrm{FePO}_{4}$ powder samples and their modified physicochemical surface and bulk properties, which affected the conversion and selectivity in the partial oxidation (POX) mechanism of $\mathrm{CH}_{4}$, were investigated. Temperature-programmed re-oxidation (TPRO) profiles indicated that the type of moieties utilised in the procedures, determined the re-oxidizing pathway of the reduced multiphase $\mathrm{FePO}_{4}$ system. Mössbauer spectroscopy measurements along with X-ray diffraction (XRD) examination of neat, hydrogenated and spent catalytic compounds, demonstrated a variation of the phosphate into a mixture of crystallites, which depended on operating process conditions (for example time-on-stream). The Mössbauer spectra revealed the change of the initial ferric orthophosphate, $\mathrm{FePO}_{4}(\mathrm{tdm})$, to the divalent metal form, iron(॥) pyrophosphate $\left(\mathrm{Fe}_{2} \mathrm{P}_{2} \mathrm{O}_{7}\right)$; thereafter, reactivity was governed by the interaction (strength) with individual oxidizing agents. The $\mathrm{Fe}^{3+} \leftrightarrow \mathrm{Fe}^{2+}$ chemical redox cycle can play a key mechanistic role in tailored multistep design, while the advantage of iron-based heterogeneous catalysis primarily lies in being inexpensive and comprising non-critical raw resources. When compared to the other catalysts reported in the literature, the $\mathrm{FePO}_{4}$-tdm phase catalysts showed in this work exhibited a high activity towards methanol i.e., $12.3 \times 10^{-3} \mu \mathrm{mol}_{\mathrm{MeOH}} \mathrm{g}_{\mathrm{cat}} \mathrm{h}^{-1}$ using $\mathrm{N}_{2} \mathrm{O}$ as an oxidant. This catalyst also showed a high activity with $\mathrm{O}_{2}$ as an oxidant $\left(5.3 \times 10^{-3} \mu \mathrm{mol}_{\mathrm{MeOH}} \mathrm{g}_{\mathrm{cat}} \mathrm{h}^{-1}\right)$. Further investigations will include continuous reactor unit engineering optimisation.

\section{Introduction}

The direct conversion of methane to methanol has been attracting considerable attention because of its great potential application in the efficient utilization of abundant natural gas reserves. In the last decade a number of interesting approaches was suggested for the effective implementation of this difficult transformation. ${ }^{1}$ A most attractive approach is to convert the

${ }^{a}$ Department of Catalysis and Chemical Reaction Engineering, National Institute of Chemistry, Hajdrihova 19, 1001 Ljubljana, Slovenia. E-mail: dasireddy@ki.si; Fax: +3861 4760300; Tel: +38614760504

${ }^{b}$ Department of Low and Medium Energy Physics, "Jozef Stefan" Institute, Jamova cesta 39, 1000 Ljubljana, Slovenia

${ }^{c}$ Physics Department, Durban University of Technology, Durban 4000, South Africa ${ }^{d}$ School of Chemistry and Physcis, University of KwaZulu Natal, Durban 4000, South Africa

$\dagger$ Electronic supplementary information (ESI) available. See DOI: 10.1039/c9ra02327e natural gas into products such as methanol, which under ambient temperature and pressure is a liquid. ${ }^{2}$ However, over the past few decades, the conversion of methane to methanol has remained as one of the major unrequited challenges in chemistry. To activate methane, usually high temperatures are required. At these temperatures, formed methanol undergoes further oxidation to $\mathrm{CO}_{2}$ and $\mathrm{H}_{2} \mathrm{O}$, as illustrated below.,

$$
\begin{aligned}
\mathrm{CH}_{4} \stackrel{+\frac{1}{2} \mathrm{O}_{2}}{\longrightarrow} \mathrm{CH}_{3} \mathrm{OH} \stackrel{+\frac{1}{2} \mathrm{O}_{2}}{\longrightarrow} \mathrm{HCHO} \\
\stackrel{+\frac{1}{2} \mathrm{O}_{2}}{\longrightarrow} \mathrm{HCOOH} \stackrel{+\frac{1}{2} \mathrm{O}_{2}}{\longrightarrow} \mathrm{CO}_{2}+\mathrm{H}_{2} \mathrm{O}
\end{aligned}
$$

Methanol is formed via methane oxidation by $\alpha$-oxygen, $\mathrm{CH}_{4}+\left(\mathrm{M}^{\mathrm{n}}-\mathrm{O}^{*-}\right)_{\alpha}$, migrated from $\alpha$-oxygen sites. It is generally accepted that $\alpha$-sites perform the oxidation via the reversible 
redox transition $\mathbf{M}^{n} \leftrightarrow \mathbf{M}^{n+1.3}$. Much of the work on the variety of catalysts that have been investigated for partial oxidation of methane to methanol has been summarized in recent literature reports. ${ }^{5-7}$ The majority of the studies involved supported metal oxide catalysts, primarily vanadium and molybdenum oxide. ${ }^{1,2}$ Higher activity and selectivity to the desired products over mixed metal oxide catalysts can be attributed to the formation of easily reducible metal oxide species caused by interactions between the metals. Loading of supported phase below the monolayer coverage has been shown to be preferable for the high production of formaldehyde and methanol from methane. ${ }^{\mathbf{8} 9}$ Otsuka et al. ${ }^{\mathbf{1 , 1 0}}$ reported that the conversion of methane is accelerated by co-feeding hydrogen with oxygen over several iron containing catalysts. The co-feeding of hydrogen induces the formation of methanol over $\mathrm{FePO}_{4}$, $\mathrm{FeAsO}_{4}$ and FAPO-5 (Fe : $\left.\mathrm{Al}: \mathrm{P}=0.1: 0.9: 1.0\right)$ catalysts at atmospheric pressure and in the temperature range of 350$500{ }^{\circ} \mathrm{C}$. Thus, in order to design a better catalyst, it is quite important to understand which the effective and/or ineffective iron sites are in the selective oxidation of methane to methanol.

A low temperature $\left(150{ }^{\circ} \mathrm{C}\right)$, isothermal, gas-phase recyclable process was described for the partial oxidation of methane to methanol over Cu/ZSM-5 by Sheppard et al., ${ }^{11}$ which showed a stable formation of methanol for a long period of time. Depending on the iron content and activation conditions, a variety of Fe species may be available in the zeolite, ranging from isolated $\mathrm{Fe}(\mathrm{II})$ and $\mathrm{Fe}(\mathrm{III})$ cations and oligonuclear Fe complexes up to large agglomerates of iron oxide. FeZSM-5 zeolites have a long application history as catalysts for oxidations by $\mathrm{N}_{2} \mathrm{O} .^{3,4,12}$ Methanol and dimethyl ether (DME) were the products extracted from the catalytic surface. Cofeeding water strongly increased methanol selectivity, which attained a fractional concentration of $62 \%$ at $275{ }^{\circ} \mathrm{C}$. The location, dispersion and environment (acidic or alkaline) of iron sites and the nature of oxidant are key factors in determining the catalytic performances of iron-containing mesoporous materials for selective oxidation reactions. ${ }^{\mathbf{1 3 4}}$ Shiota and Yoshizawa ${ }^{15}$ have computed and analysed the reactions of the first row $\mathrm{MO}^{+}$complexes $(\mathrm{M}=\mathrm{Sc}, \mathrm{Ti}, \mathrm{V}, \mathrm{Cr}, \mathrm{Mn}, \mathrm{Fe}, \mathrm{Co}, \mathrm{Ni}$ and $\mathrm{Cu}$ ) and methane, which can competitively form methanol and methyl radical. Anderson et al. ${ }^{\mathbf{1 6}}$ carried out a systematic study of the conversion of methane using a number of metal oxide catalysts. They demonstrated that cobalt oxide is the most active single component catalyst which resulted in a high conversion, but with a very low selectivity towards methanol synthesis.

Štolcová and co-workers ${ }^{17,18}$ examined the influence of structure and reactivity of copper iron pyrophosphate catalysts for the selective oxidation of methane using $\mathrm{O}_{2}$ and $\mathrm{N}_{2} \mathrm{O}$ as oxidizing agents. These oxidants showed appreciable impact on the onset of both methane conversion and the primary oxidation products. The catalytic results showed that the lattice oxygen of the catalyst could react with methane molecules producing methanol and that replenishment of the lattice oxygen by $\mathrm{N}_{2} \mathrm{O}$ takes places rather readily and rapidly. Wang et $a l .{ }^{13}$ showed the use of $\mathrm{N}_{2} \mathrm{O}$ oxidant for the epoxidation of
$\mathrm{C}_{3} \mathrm{H}_{6}$ over iron-containing catalysts. Iron is peculiar for obtaining high selectivity to propylene oxide, and the modification of the iron sites with an alkali metal salt can promote the $\mathrm{C}_{3} \mathrm{H}_{6}$ epoxidation. Christos et al. ${ }^{19}$ have shown that the reactivity of commercial zeolite-based catalysts containing $\mathrm{Fe}$ and/or $\mathrm{Cu}$ cations for the partial oxidation of methane is influenced by the acid sites strength and concentration in the catalyst which depends on the $\mathrm{Si} / \mathrm{Al}$ molar ratio and type of zeolite. It was shown that the $\mathrm{Fe}$ cations are responsible for the superior oxygenates productivity, while the crucial role of $\mathrm{Cu}$ is to maintain high $\mathrm{MeOH}$ selectivity by suppressing the production of the deeper oxidation product, $\mathrm{HCOOH}$. Partial oxidation of methane over iron phosphate supported on silica produced high formaldehyde yields. ${ }^{17,20}$ In the literature, ${ }^{18,21}$ it has been shown that the nature of the oxidant, however, was observed to play a vital role in favoring yield towards methanol. In line with the state of the art direct conversion of methane to methanol, we have undertaken this work with the aim to investigate which of the oxidant species, $\mathrm{O}_{2}, \mathrm{H}_{2} \mathrm{O}$ or $\mathrm{N}_{2} \mathrm{O}$, would lead to achieving a high yield of methanol over $\mathrm{FePO}_{4}$ catalysts. As an attempt to achieve this objective, an ammonia gel method was employed to synthesize $\mathrm{FePO}_{4}$ catalyst, the resulting catalyst structures were then revealed by different characterisation techniques and the influence of oxidants on the structure and phase of $\mathrm{FePO}_{4}$ during the reaction was examined.

\section{Experiment}

\subsection{Synthesis of the catalyst}

The catalysts were synthesized by the ammonia gel method described by Friedrich et $a .^{22-24}$ This catalytic preparation methodology was chosen because of its simplicity and to achieve a better control of particle size and morphology of the active phase. In essence, an appropriate amount of ferric nitrate, $\mathrm{Fe}\left(\mathrm{NO}_{3}\right)_{3} \cdot 9 \mathrm{H}_{2} \mathrm{O}$ (99\%, Sigma Aldrich) was dissolved in water and then a dilute ammonium solution $\left(25 \% \mathrm{NH}_{3}\right.$ in $\mathrm{H}_{2} \mathrm{O}$, Sigma Aldrich) was added. This led to precipitation and formation of iron(III) hydroxide (brown gel). Orthophosphoric acid (85\% $\mathrm{H}_{3} \mathrm{PO}_{4}$, Sigma Aldrich) was added while stirring the gel, followed by a $40 \mathrm{wt} \%$ silica solution. The stirred mixture was then heated to $60{ }^{\circ} \mathrm{C}$ and kept at this temperature for $2 \mathrm{~h}$. The obtained gel was heated at $90{ }^{\circ} \mathrm{C}$ for $12 \mathrm{~h}$, and the dried solid achieved was then calcined at a temperature $500{ }^{\circ} \mathrm{C}$ for $4 \mathrm{~h}$ in a 2 bar flow of air.

\subsection{Characterization of catalysts}

The characterizations of fresh and used catalysts are described below. Nitrogen physisorption analyses were carried out by degassing the catalysts under $\mathrm{N}_{2}$ flow for $4 \mathrm{~h}$ at $200{ }^{\circ} \mathrm{C}$. The degassed samples were analysed in the Micromeritics ASAP 2020 multi-point surface area and porosity analyser. Powder Xray diffraction (XRD) studies were conducted using the PANalytical X'Pert Pro instrument. Scanning from 10 to $90^{\circ}$ was carried out using the $\mathrm{CuK} \alpha$-radiation source with the wavelength of $0.15406 \mathrm{~nm}$. Temperature programmed reductionoxidation (TPRO) was performed using the Micromeritics 2920 
Autochem II Chemisorption Analyser. Initially, the reduction of the catalyst was done using $4.9 \mathrm{~mol}^{\circ} \mathrm{H}_{2}$ in $\mathrm{Ar}$ as a reducing agent as in the method described in. ${ }^{25,26}$ Temperature programmed desorption (TPD) was carried out using the Micromeritics 2920 Autochem II Chemisorption Analyser as well. After reduction, the catalysts were pre-treated at $350{ }^{\circ} \mathrm{C}$ under the stream of helium for $60 \mathrm{~min}$. The temperature was consequently decreased to $80{ }^{\circ} \mathrm{C}$. Appropriate pre-chosen gas was passed over the catalysts $\left(10 \mathrm{~mol}^{\circ} \mathrm{CO}_{2}\right.$ in $\mathrm{He}$ or $4.9 \mathrm{~mol} \% \mathrm{H}_{2}$ in

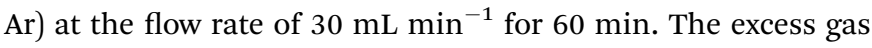
was removed by purging with helium for $30 \mathrm{~min}$. The temperature was thereafter gradually raised to $900{ }^{\circ} \mathrm{C}$ by ramping at $10{ }^{\circ} \mathrm{C} \mathrm{min}^{-1}$ under the flow of helium, wherein the desorption data of $\mathrm{CO}_{2}$ or $\mathrm{H}_{2}$ was recorded. The desorption data of $\mathrm{O}_{2}, \mathrm{H}_{2} \mathrm{O}$ and $\mathrm{N}_{2} \mathrm{O}$ were also recorded in the same procedure. Metal dispersion is calculated using CO chemisorption which is illustrated in literature $\mathrm{e}^{24,26}$

The structural morphology of the prepared catalysts was studied using field-emission scanning electron microscope (Carl Zeiss, FE-SEM SUPRA 35VP), equipped with energydispersive X-ray spectroscopy hardware (Oxford Instruments, model INCA 400). Particle size, morphology and elemental mapping performed by EDXS analyses were investigated using Cs corrected scanning transmission electron microscope JEOL ARM $200 \mathrm{CF}$ equipped with JEOL Centurio $100 \mathrm{~mm}^{2}$ EDXS system. ${ }^{57}$ Fe-Mössbauer spectroscopy measurements were made at room temperature (RT) in conventional transmission geometry with a ${ }^{57}$ Co source embedded in Rh matrix.

\subsection{Partial oxidation of methane}

The catalytic partial oxidation runs using the $\mathrm{FePO}_{4}$ catalysts were carried out in a horizontal fixed-bed U-shaped quartz reactor as described in. ${ }^{27,28}$ The catalyst $(\sim 0.4 \mathrm{~g})$ was placed in the middle of the reactor and a flow of $\mathrm{N}_{2}\left(30 \mathrm{~mL} \mathrm{~min}{ }^{-1}\right)$ was introduced into the reactor at a temperature of $200{ }^{\circ} \mathrm{C}$ in order to remove the physisorbed gases from the surface of the catalyst. The catalytic runs were carried out under atmospheric pressure at the temperature range of $200-500{ }^{\circ} \mathrm{C}$ using undiluted high purity $\mathrm{CH}_{4}(99.95 \%)$ and the appropriate oxidant $\left(\mathrm{O}_{2}\right.$, $\mathrm{N}_{2} \mathrm{O}$ or $\mathrm{H}_{2} \mathrm{O}$ ) at flow rate of $60 \mathrm{~mL} \mathrm{~min}^{-1}$, corresponding to the gas hour space velocity (GHSV) of $3600 \mathrm{~h}^{-1}$ with a methane to oxidant ratio of $1: 1$. The gas products were analysed using an Agilent 490 Micro GC TCD equipped with CP-Molsieve and PoraPolt U columns. Reported values are given after $5 \mathrm{~h}$ of the reaction under steady-state conditions. The product mixture including methane, methanol, carbon oxides and nitrogen were analysed by online quadrupole mass spectrometry (MS). The signals in the MS are calibrated with different mole fractions of methane, methanol, carbon oxides and nitrogen in order to determine the mole composition of gases in the outflow. No other gaseous products were detected during the reaction. All the data points were recorded in duplicate with a standard deviation of $\pm 2 \%$. The carbon mass balances are in the range of 98-99\%.

The methane conversion $(\delta)$ was calculated using the following equation:

$$
\mathrm{CH}_{4} \text { conversion }\left(\delta_{\mathrm{CH}_{4}} \operatorname{mol} \%\right)=\frac{\left(\left[\mathrm{CH}_{4}\right]_{\text {in }}-\left[\mathrm{CH}_{4}\right]_{\text {out }}\right)}{\left[\mathrm{CH}_{4}\right]_{\text {in }}} \times 100
$$

Oxidant conversion $\left(\delta_{\text {oxi }}\right.$ mol $\left.\%\right)=\frac{[\text { moles of oxidant }]_{\text {out }}}{[\text { moles of oxidant }]_{\text {in }}} \times 100$

$\mathrm{CH}_{3} \mathrm{OH}$ selectivity $\left(S_{\mathrm{CH}_{3} \mathrm{OH}} \mathrm{mol} \%\right)=\frac{\left[\mathrm{CH}_{3} \mathrm{OH}\right]_{\text {out }}}{\left[\mathrm{CH}_{4}\right]_{\text {in }}-\left[\mathrm{CH}_{4}\right]_{\text {out }}} \times 100$

\section{Results and discussion}

The effect of reaction temperature on methane conversion over $\mathrm{FePO}_{4}$ catalyst with different oxidative environments was investigated as shown in Fig. 1. Methane conversion with $\mathrm{N}_{2} \mathrm{O}$ and $\mathrm{O}_{2}$ increases with temperature; however when $\mathrm{H}_{2} \mathrm{O}$ is used as an oxidant, methane conversion increases at much lower linear rate with temperature. Furthermore, the maximum methane conversion (17\%) was obtained when oxygen is used as an oxidant at a temperature of $500{ }^{\circ} \mathrm{C}$, the highest reaction temperature in this study. The differences in conversion rates clearly show that selective oxidation of methane on $\mathrm{FePO}_{4}$ is influenced by the nature of the oxidant. These facts strongly suggest that the reaction mechanisms are different. ${ }^{29}$ This conclusion is strengthened by the greater conversions with $\mathrm{O}_{2}$ than $\mathrm{N}_{2} \mathrm{O}$, which is in agreement with the reaction thermodynamics and the activation energy differences between these two oxidants. ${ }^{1}$ This means that there exists a lower kinetic barrier for $\mathrm{O}_{2}$ than $\mathrm{N}_{2} \mathrm{O}$ in catalytic selective oxidation of methane.

When considering the effect of temperature on the methane conversion, two factors need to be considered. Firstly, methane conversion will depend on the oxidant feed concentration, secondly, even if total oxidant consumption occurs, methane conversion can change with a change in selectivity. Most of the studies $^{2,3,11,18,30,31}$ reported in literature have examined the effect of temperature over a range varying from approximately 300 to $500{ }^{\circ} \mathrm{C}$. It has been found that very low conversion occurs until a critical temperature is reached, after which a very rapid rise in conversion is observed (Fig. 1). This usually corresponds to total oxidant consumption. Typically the products obtained in the partial oxidation of reaction consist of $\mathrm{CH}_{3} \mathrm{OH}, \mathrm{CO}, \mathrm{CO}_{2}, \mathrm{HCHO}$ and $\mathrm{H}_{2} \mathrm{O} . \mathrm{CO}_{2}$ and $\mathrm{H}_{2} \mathrm{O}$ are formed initially at temperatures below $300{ }^{\circ} \mathrm{C}$. At $400{ }^{\circ} \mathrm{C}$ both selectivity and yield of methanol are found to pass through a maximum before decreasing as the temperature is increased further (Fig. 2). Methanol formation is accompanied by the production of $\mathrm{CO}$ along with $\mathrm{CO}_{2}$ and $\mathrm{H}_{2} \mathrm{O}$. It was generally found that increasing the temperature well above the self-ignition temperature of methanol favors the production of $\mathrm{CO}, \mathrm{CO}_{2}$ and $\mathrm{H}_{2} \mathrm{O}$ at the expense of methanol., 10,18

To make a better comparison of catalytic performance among the oxidants, we further carried out the reactions with various flow rates between a GHSV of 2000 and $7000 \mathrm{~h}^{-1}$. The conversion of methane increased and the selectivity to 


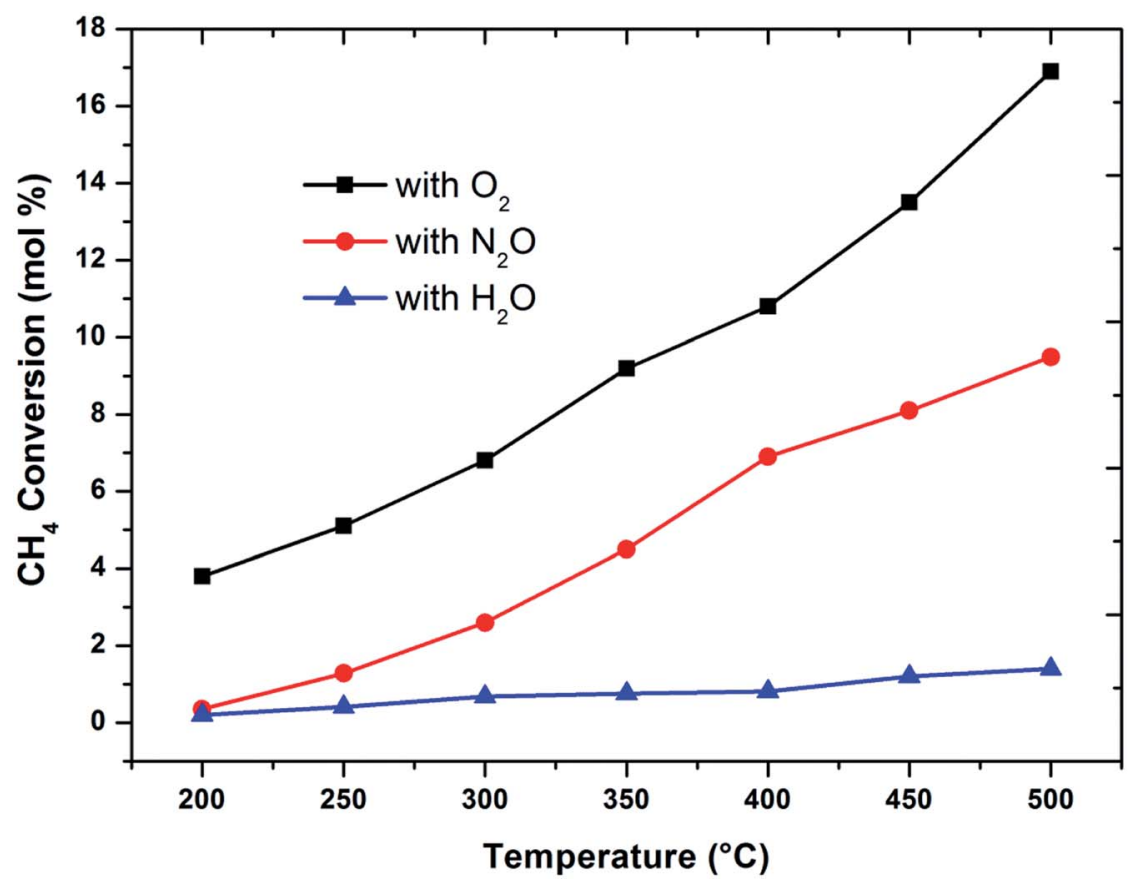

Fig. 1 Influence of oxidant on methane conversion over $\mathrm{FePO}_{4}$ catalyst with varying temperature $\left(\mathrm{GHSV}=3600 \mathrm{~h}^{-1}\right.$ and methane to oxidant ratio of $1: 1$ ).

methanol decreased with decrease in the flow rate as expected (ESI, Fig. S1†). From these data, the plot (Fig. 3) of methanol selectivity versus methane conversion was constructed. The selectivity towards methanol was very high at lower methane conversion at higher flow rate. However, when the comparison was made at higher methane conversion, the selectivity to methanol was the highest when $\mathrm{N}_{2} \mathrm{O}$ is used as oxidant. In addition to that, the selectivity of methanol at low conversions $(<2 \%)$ of methane was almost identical (see first two data points at nearly $100 \%$ selectivity in Fig. 3 ). By elevating the reaction temperature at these conditions also, methanol selectivity gradually dropped and raised the $\mathrm{CO}$ production. This was

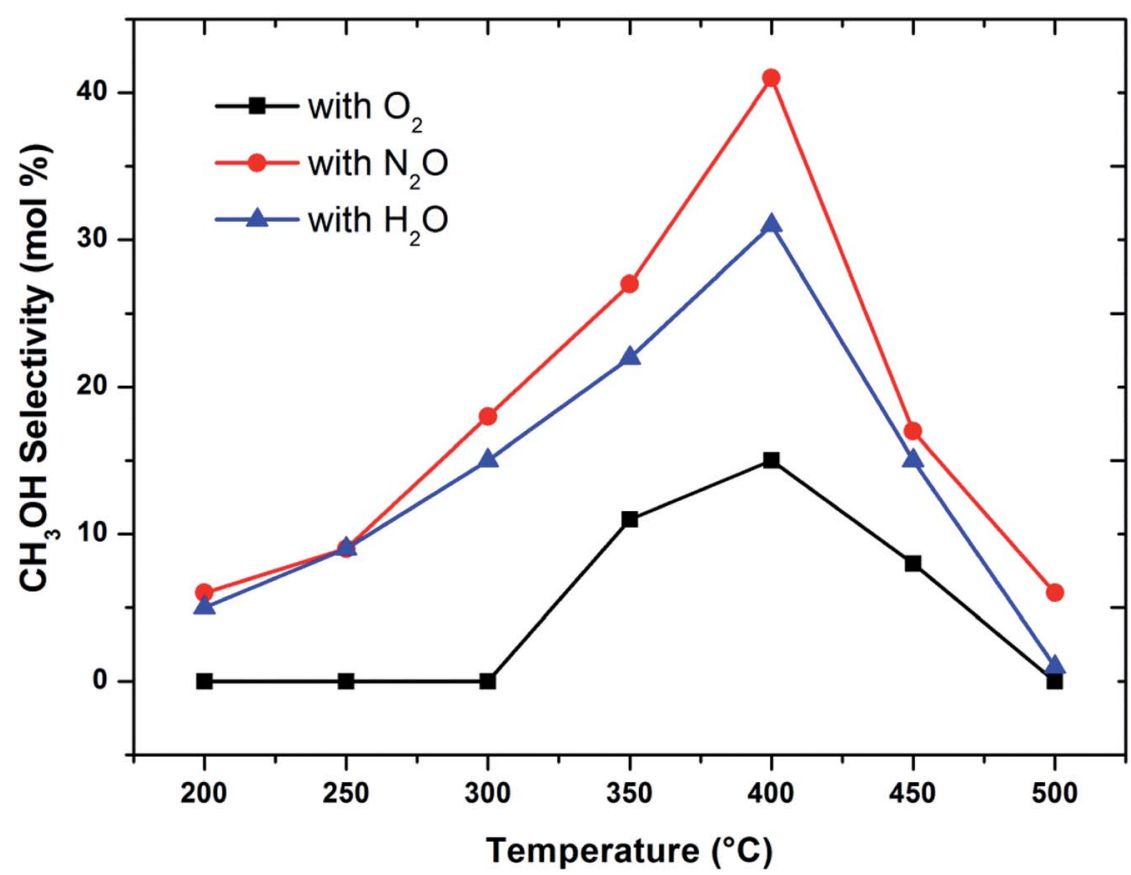

Fig. 2 Influence of oxidant on $\mathrm{CH}_{3} \mathrm{OH}$ selectivity in methane partial oxidation reaction over $\mathrm{FePO}_{4}$ catalyst with varying temperature (GHSV $=$ $3600 \mathrm{~h}^{-1}$ and methane to oxidant ratio of $1: 1$ ). 

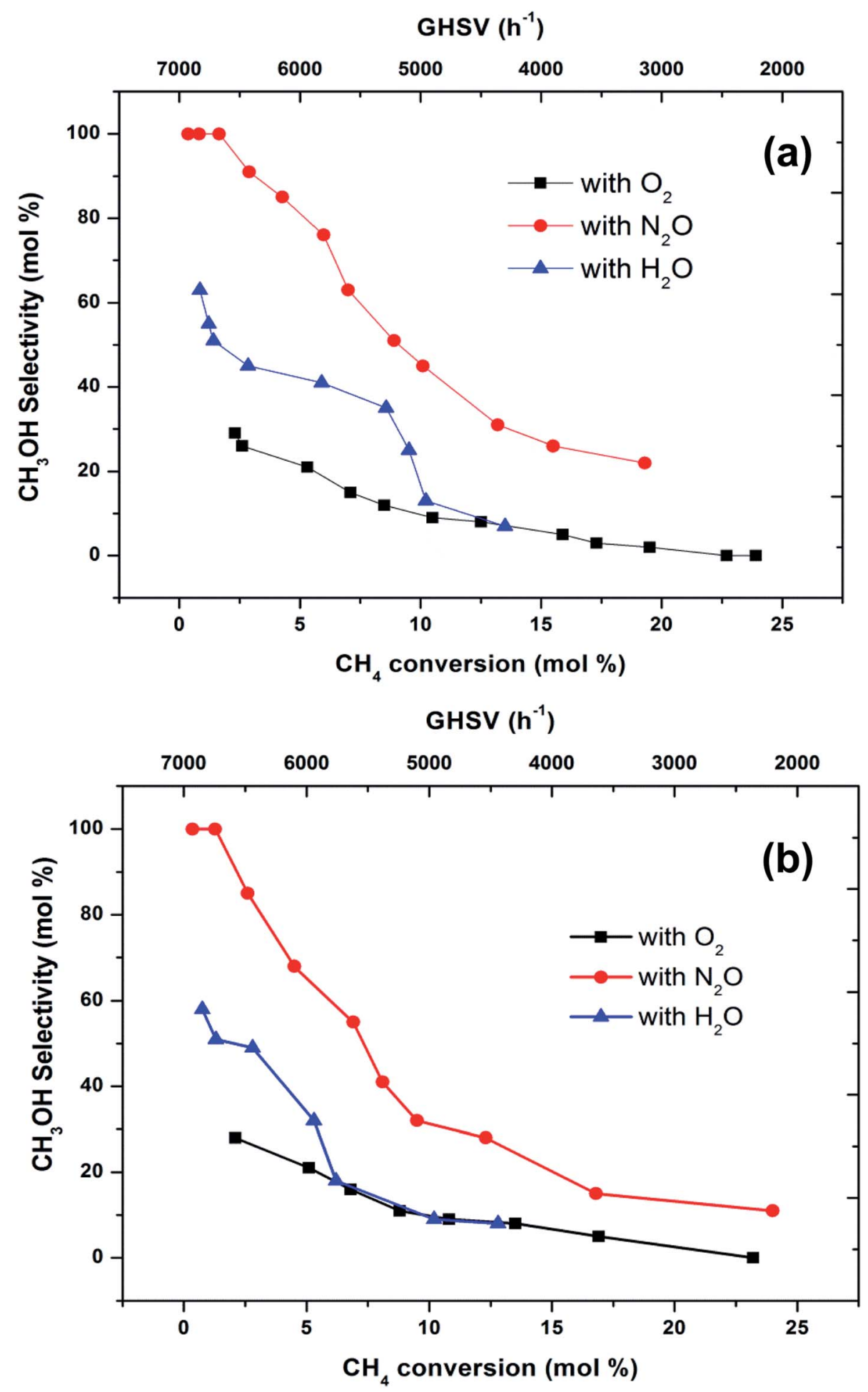

Fig. 3 Selectivity towards methanol varying with methane conversion over FePO 4 catalyst at the temperatures of (a) $300{ }^{\circ} \mathrm{C}$ and (b) $400{ }^{\circ} \mathrm{C}$ (GHSV $=2000-7000 \mathrm{~h}^{-1}$, methane to oxidant ratio of $1: 1$ ).

a consequence of the low stability of methanol at higher temperatures and thereby it over oxidised to carbon oxides. It has been well recognized that the selective oxidation of methane proceeds via redox mechanism, but the pathways and product distribution depend on the nature of the oxidant and the reaction conditions. ${ }^{16,29}$

Activation of methane may occur by both hemolytic and heterolytic mechanisms. ${ }^{2,27}$ Thus the investigations of used catalysts of $\mathrm{FePO}_{4}$ might give an insight into the modified 
physicochemical properties of the catalysts which further influenced the conversion and selectivity in the partial oxidation of methane. The rate determining step would be the rupture of the $\mathrm{C}-\mathrm{H}$ bond and the formation of $\mathrm{CH}_{3}$ and $\mathrm{HO}$ radicals were postulated as the initial step., ${ }^{\mathbf{1 , 2}}$ For methane oxidation to methanol, the most strongly supported mechanism consists of consecutive conversion scheme as shown in eqn (1). The methoxy radical is an important intermediate in the reaction pathway. ${ }^{19}$ Elimination of hydrogen from methoxy radical in a reaction such as oxidative dehydrogenation gives formaldehyde which is easily converted to $\mathrm{CO}$ and $\mathrm{CO}_{2}$. Hydrogenation of the methoxy radical yields methanol. ${ }^{1}$ Stabilization of the methoxy radical by hydrogenation is a key step to achieve a high methanol yield. ${ }^{18}$ Fig. 4 shows the selectivity towards products in the partial oxidation of methane at iso-conversions of $10 \%$ and 5\%. At both iso-conversion conditions (similar conversions at the same temperature), methanol was formed in high quantity when $\mathrm{N}_{2} \mathrm{O}$ used as an oxidant. $\mathrm{CO}_{2}$ is the major product
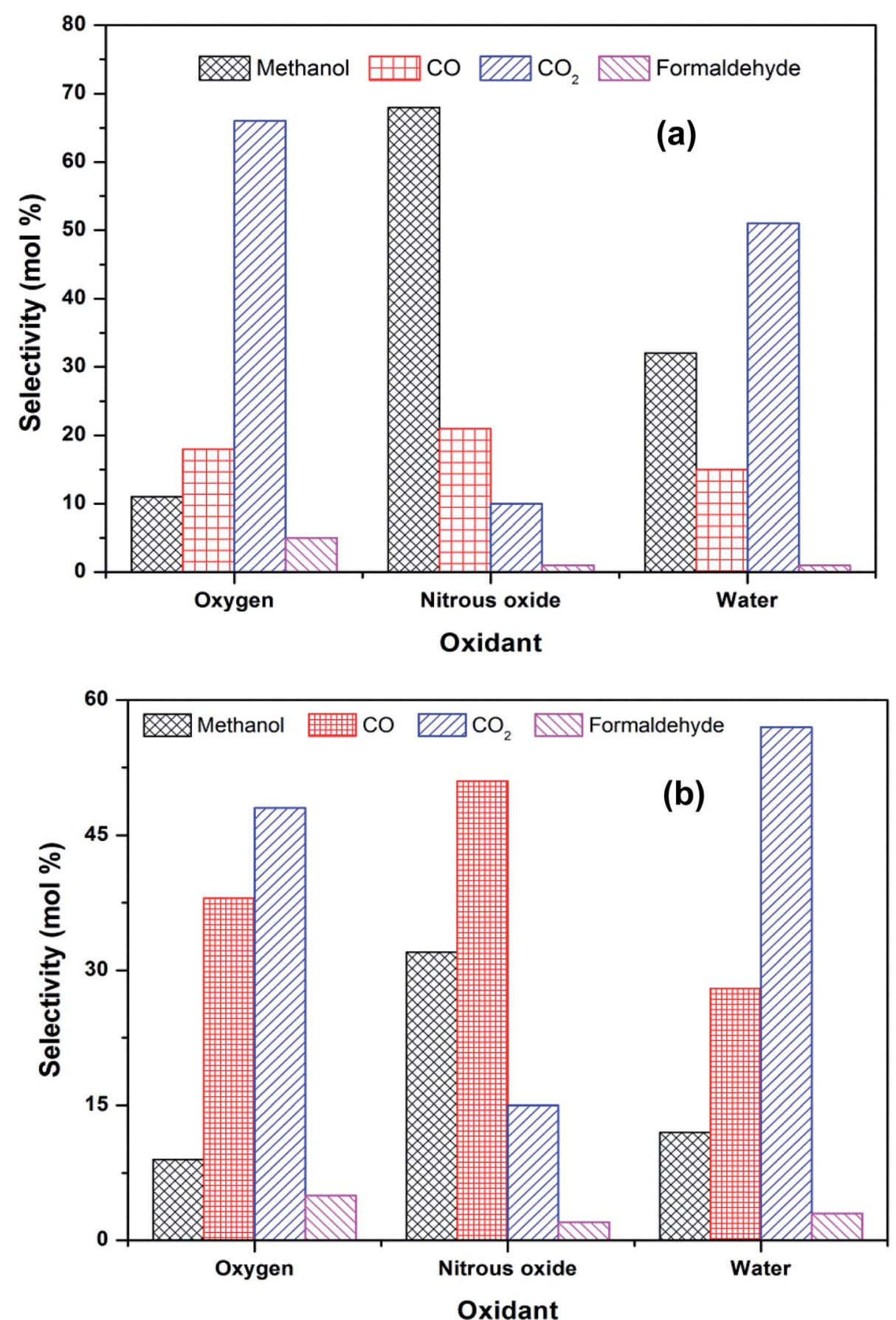

Fig. 4 Selectivity towards products in the partial oxidation of methane at an iso-conversion of (a) $5 \%$ and (b) $10 \%$ over FePO 4 catalyst with various oxidants (temperatures of $400{ }^{\circ} \mathrm{C}$ and methane to oxidant ratio of $1: 1$ ). 
with both $\mathrm{O}_{2}$ and $\mathrm{H}_{2} \mathrm{O}$. This could be either due to the further oxidation of methoxy radical to $\mathrm{CO}_{2}$ or the direct combustion of methane to $\mathrm{CO}_{2}$. On the other hand, when $\mathrm{N}_{2} \mathrm{O}$ was used, these effects were less systematic; the production rate of methanol was approximately doubled (Fig. 4). Using $\mathrm{N}_{2} \mathrm{O}$, methanol selectivity was higher, with decreased $\mathrm{CO}_{2}$ selectivity. The catalytic differences have been ascribed to the differing oxidizing power of $\mathrm{O}_{2}, \mathrm{~N}_{2} \mathrm{O}$ and $\mathrm{H}_{2} \mathrm{O}$. In accordance with the Mars-van Krevelen mechanism, ${ }^{1,2,29}$ which has been proposed, the re-oxidation of the catalyst will be less effective with $\mathrm{N}_{2} \mathrm{O}$ and $\mathrm{H}_{2} \mathrm{O}$ compared to $\mathrm{O}_{2}$. At all conditions, formaldehyde is formed in very minor quantities, which could also be due to a secondary oxidation of formaldehyde to $\mathrm{CO}$ or $\mathrm{CO}_{2}$.

Fig. 5 shows the SEM images of $\mathrm{FePO}_{4}$ catalysts treated under various conditions. The fresh catalyst possesses rough crystalline morphology with a particle sizes ranging from 50-80 nm with a homogeneous dispersion of the particles. After reduction, the agglomeration of these particles was observed. After oxidation with oxygen the crystalline nature is retained with a separate agglomerated bulk particles. After oxidation with $\mathrm{N}_{2} \mathrm{O}$ and $\mathrm{H}_{2} \mathrm{O}$, the catalysts showed a relatively poor crystalline structure and an amorphous like morphology (Fig. 5d and e). The BET surface areas, measured by the physical nitrogen adsorption for all of the samples, are presented in Table 1 . The specific surface area of fresh $\mathrm{FePO}_{4}$ was found to be $19 \mathrm{~m}^{2} \mathrm{~g}^{-1}$. However, BET surface area decreased after reduction and oxidation treatments. After reduction, the surface area of the catalyst reduced drastically to $9 \mathrm{~m}^{2} \mathrm{~g}^{-1}$, due to the blocking of the pores of the $\mathrm{FePO}_{4}$ by the amorphous carbon which formed large crystallites, as evidenced by XRD and pore-size distribution measurements.
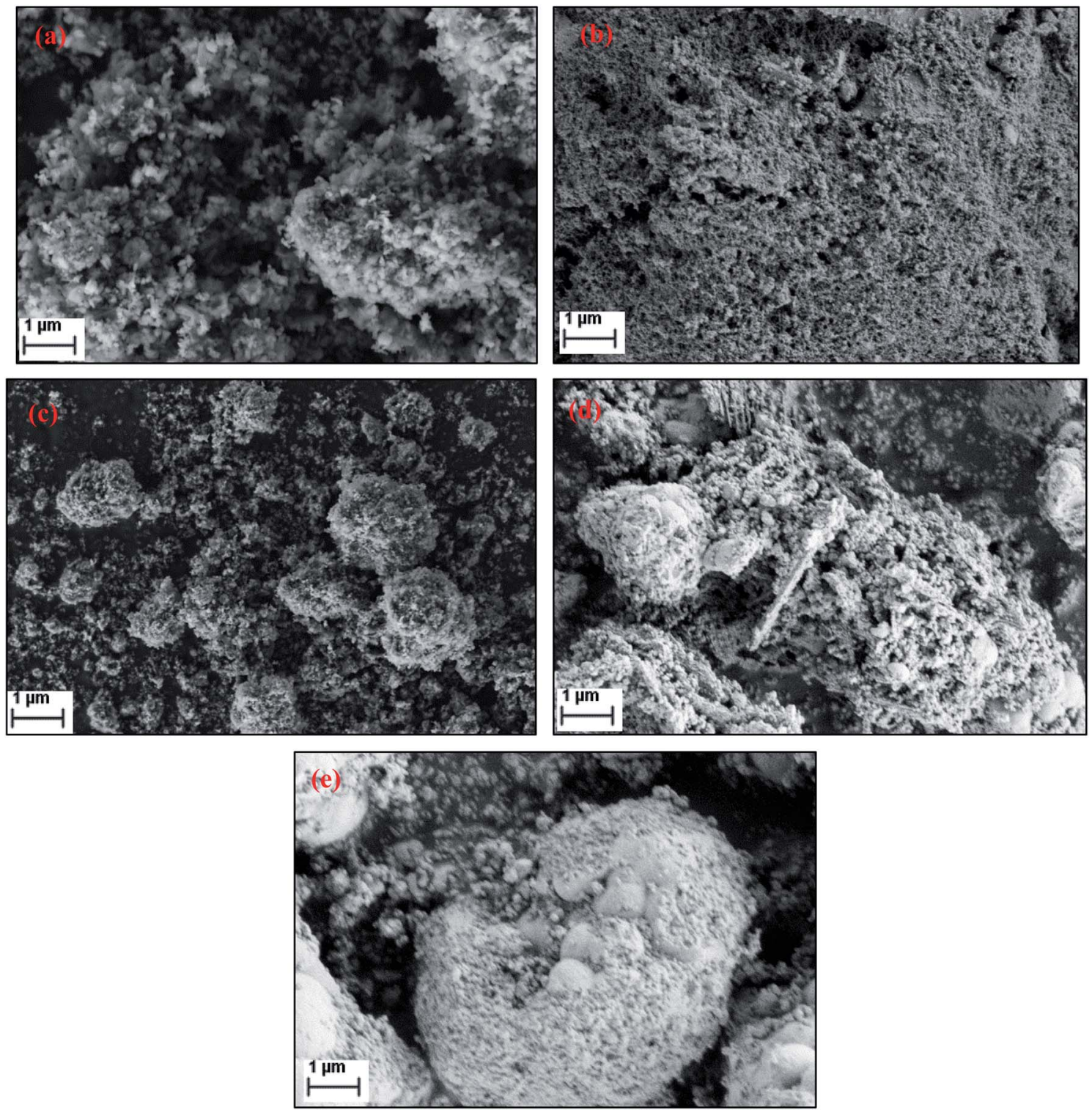

Fig. 5 Scanning electron micrographs (SEM) of $\mathrm{FePO}_{4}$ catalysts under various conditions (a) fresh, (b) reduced under $\mathrm{CH}_{4}$, (c) oxidized with $\mathrm{O}_{2}$, (d) oxidized with $\mathrm{N}_{2} \mathrm{O}$ and (e) oxidized with $\mathrm{H}_{2} \mathrm{O}$. 
Table 1 Particulate properties of fresh, reduced and oxidized $\mathrm{FePO}_{4}$ nanocomposite catalysts

\begin{tabular}{lllll}
\hline Catalyst condition & Surface area $\left(\mathrm{m}^{2} \mathrm{~g}^{-1}\right)$ & $\begin{array}{l}\text { Pore volume } \\
\left(\mathrm{cm}^{3} \mathrm{~g}^{-1}\right)\end{array}$ & Metal dispersion ${ }^{a}(\%)$ & 27.8 \\
Fresh & 19 & 0.021 & 10.3 & 28 \\
Reduced (with $\mathrm{CH}_{4}$ ) catalyst & 9 & 0.015 & 22.3 & 41 \\
Oxidized (with $\mathrm{O}_{2}$ ) catalyst & 15 & 0.020 & 32 \\
Oxidized (with $\mathrm{N}_{2} \mathrm{O}$ ) catalyst & 12 & 0.019 & 17.3 & 35 \\
Oxidized (with $\mathrm{H}_{2} \mathrm{O}$ ) catalyst & 13 & 0.018 & 15.8 & 35
\end{tabular}

\footnotetext{
${ }^{a}$ Calculated from CO chemisorption ${ }^{32} \cdot{ }^{b}$ Average crystallite size calculated by Scherrer equation.
}

The $\mathrm{N}_{2}$ adsorption-desorption isotherms of the fresh, reduced and oxidised catalysts (ESI, Fig. $\mathrm{S} 2 \dagger$ ) can be categorised as the type IV isotherms, with a distinct hysteresis loop, observed in the relative pressure $\left(P / P_{\mathrm{o}}\right)$ range of $0.47-0.79 .^{33}$ The pore-size distribution, calculated from the desorption counterpart using Barrett-Joyner-Halenda (BJH) method, showed a dominant peak in the mesoporous range (ESI, Fig. S3†). The metal dispersion of Fe species was calculated from CO chemisorption. Metal dispersion showed the similar trend to surface area, as the fresh catalyst showed a high metal dispersion compared to the reduced and oxidised catalysts. Among the oxidised catalysts, the catalyst oxidised with oxygen showed a higher metal dispersion compared to the catalysts oxidised with $\mathrm{N}_{2} \mathrm{O}$ or $\mathrm{H}_{2} \mathrm{O}$. This could be due to the amount of available oxygen present in $\mathrm{N}_{2} \mathrm{O}$ or $\mathrm{H}_{2} \mathrm{O}$. This shows that the nitrous oxide or water provides adequate oxidation of reduced sites of the catalyst. This may explain the fact that the number of active sites is altered and the nature of the active sites of the oxidised catalyst remained unchanged.

To investigate the phase transformations occurred during reduction and oxidation, powder XRD and Mössbauer analysis of the reduced and oxidized samples were carried out. The reduced sample was obtained using reducing the fresh $\mathrm{FePO}_{4}$ catalyst under $10 \% \mathrm{CH}_{4}$ in Ar. In the TPR profile, the catalyst showed three peaks at the temperatures of 492,625 and $815{ }^{\circ} \mathrm{C}$ (Fig. 6). These peaks represent reduction of $\mathrm{FePO}_{4}$ to $\mathrm{Fe}_{2} \mathrm{P}_{2} \mathrm{O}_{7}$ as suggested in: ${ }^{22,34}$

$$
\begin{aligned}
& \mathrm{FePO}_{4}(\text { tridymite }) \stackrel{400-650{ }^{\circ} \mathrm{C}}{\longrightarrow} \beta-\mathrm{Fe}_{3}\left(\mathrm{P}_{2} \mathrm{O}_{7}\right)_{2} \\
& \stackrel{700-850{ }^{\circ} \mathrm{C}}{\longrightarrow} \mathrm{Fe}_{2} \mathrm{P}_{2} \mathrm{O}_{7} \text { (pyrophosphate) }
\end{aligned}
$$

As reported in the literature, ${ }^{35,36}$ the first step in the reduction occurs above the temperatures of $500{ }^{\circ} \mathrm{C}$. The use of $\mathrm{CH}_{4}$ as reductant in this study accelerated the reduction, probably due to the activation and spill over of hydrogen from the metal centers to the iron phosphate.

After the reduction, the oxidation was conducted using $\mathrm{O}_{2}$, $\mathrm{N}_{2} \mathrm{O}$ and $\mathrm{H}_{2} \mathrm{O}$ as oxidants (10\% of oxidant in $\mathrm{Ar}$ ), separately. The TPRO profile under $\mathrm{H}_{2} \mathrm{O}$ exhibited a very wide range of oxidation profile in the temperature ranging from $200-370{ }^{\circ} \mathrm{C}$ (Fig. 7). When $\mathrm{N}_{2} \mathrm{O}$ is used an oxidant, only one peak was exhibited and

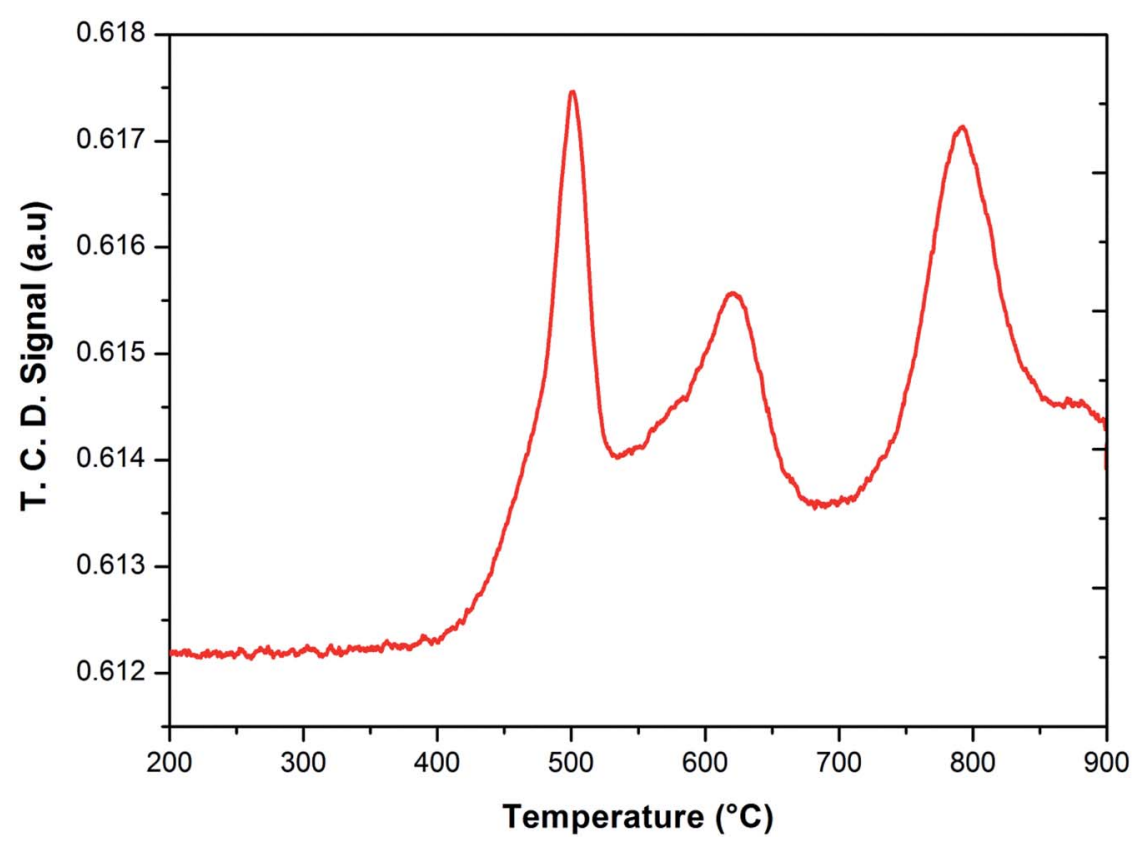

Fig. 6 Temperature programmed reduction of $\mathrm{FePO}_{4}$ catalyst under $10 \% \mathrm{CH}_{4}$ in $\mathrm{Ar}$. 


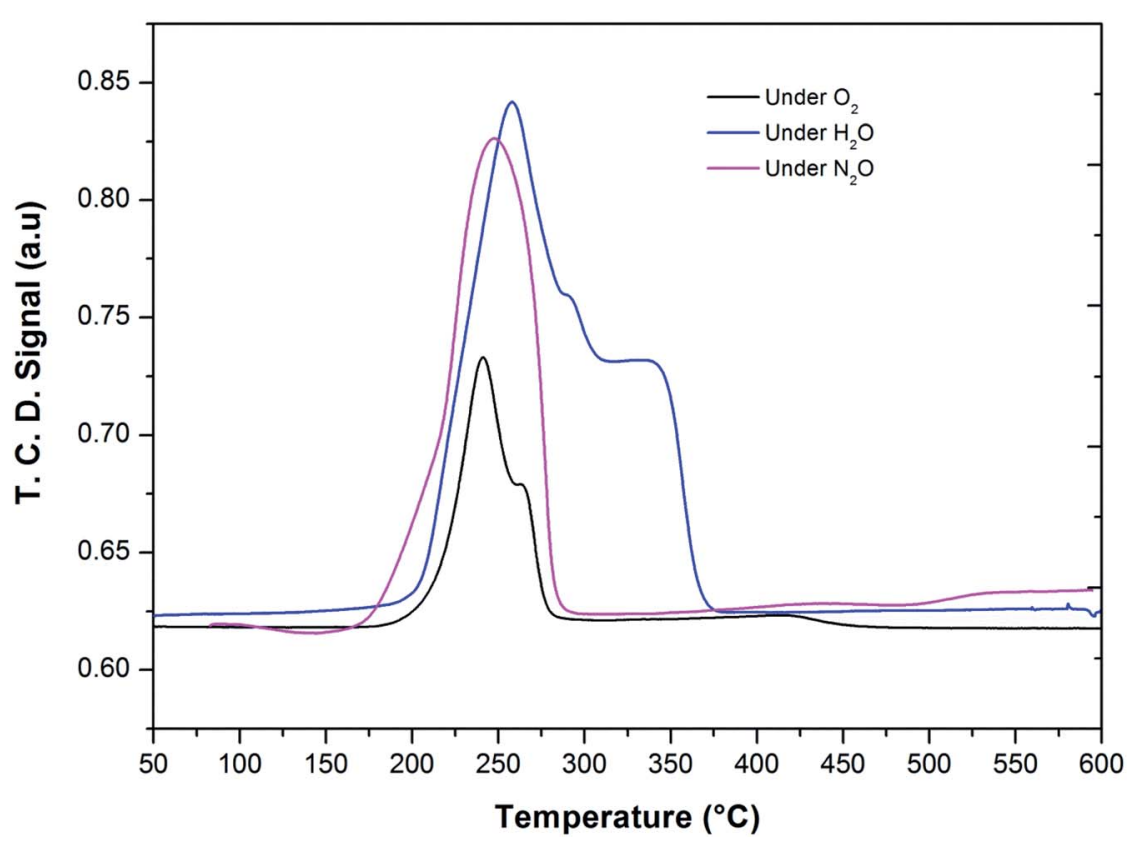

Fig. 7 Temperature programmed reduction-oxidation (TPRO) profiles of $\mathrm{FePO}_{4}$ catalyst under various oxidant environments.

two peaks in the profile occurred with $\mathrm{O}_{2}$ as oxidant. There were no peaks observed above $500{ }^{\circ} \mathrm{C}$, in the TPRO profiles. Various literature reports ${ }^{37,38}$ stated that the oxidative transformation of iron pyrophosphate phase to quartz phase occurs in two steps as below:

$$
\begin{aligned}
\mathrm{Fe}_{2} \mathrm{P}_{2} \mathrm{O}_{7} \text { (pyrophosphate) } & \stackrel{<500{ }^{\circ} \mathrm{C}}{\longrightarrow} \alpha-\mathrm{Fe}_{3}\left(\mathrm{P}_{2} \mathrm{O}_{7}\right)_{2} \\
& \stackrel{>500{ }^{\circ} \mathrm{C}}{\longrightarrow} \mathrm{FePO}_{4} \text { (quartz) }
\end{aligned}
$$

The formation of the quartz type phase has been reported in the literature; however, it was formed at temperatures above $500{ }^{\circ} \mathrm{C} .{ }^{39}$ However, it was also observed that the transformation between the $\alpha$-phase and $\mathrm{Fe}_{2} \mathrm{P}_{2} \mathrm{O}_{7}$ is reversible. Thus, from TPRO profiles, it is evident that the type of oxidant used in the re-oxidation influenced the re-oxidation path way of reduced $\mathrm{FePO}_{4}$ catalyst. The powder XRD patterns of the fresh, reduced and oxidized catalysts are shown in Fig. 8.

The fresh catalyst showed the presence of the $\mathrm{FePO}_{4}$ trydimite-like (tdm) phase by exhibiting a main peak at a $2 \theta=$ $34^{\circ}$ and minor peaks in the range of $24-30^{\circ}$. The XRD pattern of the reduced catalyst (with methane) shows two distinct peaks at $2 \theta$ values of $24^{\circ}$ and $30^{\circ}$, confirming the formation of the $\mathrm{Fe}_{2} \mathrm{P}_{2} \mathrm{O}_{7}$ phase range (ESI, Fig. $\mathrm{S} 4 \dagger$ ). The formation of this phase is also observed in literature ${ }^{22,37}$ when $\mathrm{FePO}_{4}$ is reduced under various hydrocarbon reduction atmospheres. When the reduced catalyst is oxidised in the presence of oxygen, the formation of the $\alpha$-phase $\left(\alpha-\mathrm{Fe}_{3}\left(\mathrm{P}_{2} \mathrm{O}_{7}\right)_{2}\right)$ is observed. The XRD profile of this catalyst showed two characteristic major peaks in the region of $2 \theta=33-36^{\circ}$ indicating the presence of $\alpha$-phase $\left(\alpha-\mathrm{Fe}_{3}\left(\mathrm{P}_{2} \mathrm{O}_{7}\right)_{2}\right)$ along with some minor peaks. Some of the XRD peaks in this region also coincide with peaks characteristic of the $\beta$-phase. ${ }^{22,37}$ The XRD profile of the catalyst oxidized with $\mathrm{N}_{2} \mathrm{O}$ also showed the presence of the $\alpha$-phase along with $\mathrm{Fe}_{2} \mathrm{P}_{2} \mathrm{O}_{7}$ phase, but absence of the $\beta$-phase which would give a peak at $2 \theta=36^{\circ}$ range (ESI, Fig. $\mathrm{S} 4 \dagger$ ). Oxidation of the catalyst in $\mathrm{H}_{2} \mathrm{O}$ showed a similar pattern to the catalyst oxidized with oxygen, but with

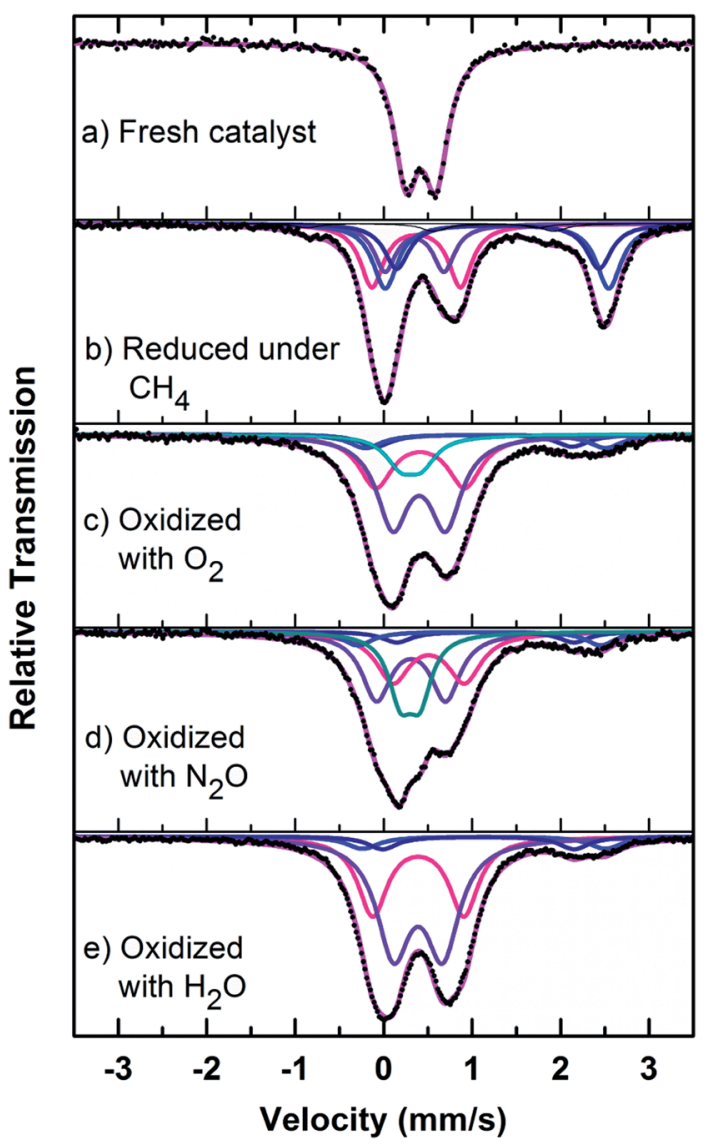

Fig. 8 Mössbauer spectra of fresh, reduced (with $\mathrm{CH}_{4}$ ) and oxidized (with $\mathrm{N}_{2} \mathrm{O}, \mathrm{O}_{2}$ and $\mathrm{H}_{2} \mathrm{O}$ ) $\mathrm{FePO}_{4}$ catalyst. 
Table 2 Mössbauer parameters, isomer shift (IS), electric quadrupole splitting (QS), $\Gamma$ (HWHM), and the attributed phases, determined from the spectra of the fresh catalyst after calcination, reduction and oxidation ${ }^{a}$

\begin{tabular}{|c|c|c|c|c|c|c|}
\hline Sample & IS $\left(\mathrm{mm} \mathrm{s}^{-1}\right)$ & $\mathrm{QS}\left(\mathrm{mm} \mathrm{s}^{-1}\right)$ & $\begin{array}{l}\Gamma \\
(\mathrm{HWHM})\left(\mathrm{mm} \mathrm{s}^{-1}\right)\end{array}$ & Fe species & Area (\%) & Attributed phase \\
\hline Fresh catalyst & $0.42(1)$ & $0.34(1)$ & 0.17 & $\mathrm{Fe}^{3+}$ & 100 & $\mathrm{FePO}_{4}$-tdm \\
\hline \multirow[t]{5}{*}{ Reduced with $\mathrm{CH}_{4}$} & $0.37(1)$ & $1.00(2)$ & 0.16 & $\mathrm{Fe}^{3+}$ & $25(2)$ & $\mathrm{Fe}_{7}\left(\mathrm{PO}_{4}\right)_{6}$ \\
\hline & $0.35(8)$ & $0.67(8)$ & 0.15 & $\mathrm{Fe}^{3+}$ & $17(2)$ & $\mathrm{FePO}_{4}$-low quartz \\
\hline & $1.28(7)$ & $2.53(8)$ & 0.17 & $\mathrm{Fe}^{2+}$ & $27(4)$ & $\mathrm{Fe}_{2} \mathrm{P}_{2} \mathrm{O}_{7}$ \\
\hline & $1.29(1)$ & $2.29(4)$ & 0.17 & $\mathrm{Fe}^{2+}$ & $19(1)$ & \\
\hline & $1.25(3)$ & $1.35(7)$ & 0.17 & $\mathrm{Fe}^{2+}$ & $3(1)$ & \\
\hline \multirow[t]{5}{*}{ Oxidized with $\mathrm{O}_{2}$} & $0.41(6)$ & $1.01(6)$ & 0.23 & $\mathrm{Fe}^{3+}$ & $28(4)$ & $\alpha-\mathrm{Fe}_{3}\left(\mathrm{P}_{2} \mathrm{O}_{7}\right)_{2}$ \\
\hline & $0.40(1)$ & $0.60(3)$ & 0.22 & $\mathrm{Fe}^{3+}$ & $46(4)$ & \\
\hline & $1.02(8)$ & $2.23(9)$ & 0.21 & $\mathrm{Fe}^{2+}$ & $6(1)$ & $\mathrm{Fe}_{2} \mathrm{P}_{2} \mathrm{O}_{7}$ \\
\hline & $1.15(4)$ & $2.71(9)$ & 0.22 & $\mathrm{Fe}^{2+}$ & $7(1)$ & \\
\hline & $0.31(1)$ & $0.24(5)$ & 0.20 & $\mathrm{Fe}^{3+}$ & $13(2)$ & $\mathrm{FePO}_{4}$-tdm \\
\hline \multirow[t]{5}{*}{ Oxidized with $\mathrm{N}_{2} \mathrm{O}$} & $0.31(1)$ & $0.78(1)$ & 0.20 & $\mathrm{Fe}^{3+}$ & $34(3)$ & $\alpha-\mathrm{Fe}_{3}\left(\mathrm{P}_{2} \mathrm{O}_{7}\right)_{2}$ \\
\hline & $0.51(2)$ & $0.81(2)$ & 0.23 & $\mathrm{Fe}^{3+}$ & $29(3)$ & \\
\hline & $1.15(2)$ & $2.00(5)$ & 0.20 & $\mathrm{Fe}^{2+}$ & $6(1)$ & $\mathrm{Fe}_{2} \mathrm{P}_{2} \mathrm{O}_{7}$ \\
\hline & $1.08(2)$ & $2.74(6)$ & 0.20 & $\mathrm{Fe}^{2+}$ & $7(1)$ & \\
\hline & $0.30(1)$ & $0.22(3)$ & 0.16 & $\mathrm{Fe}^{3+}$ & $24(1)$ & $\mathrm{FePO}_{4}$-tdm \\
\hline \multirow[t]{4}{*}{ Oxidized with $\mathrm{H}_{2} \mathrm{O}$} & $0.39(1)$ & $1.03(1)$ & 0.20 & $\mathrm{Fe}^{3+}$ & $33(1)$ & $\alpha-\mathrm{Fe}_{3}\left(\mathrm{P}_{2} \mathrm{O}_{7}\right)_{2}$ \\
\hline & $0.39(1)$ & $0.56(1)$ & 0.23 & $\mathrm{Fe}^{3+}$ & $56(2)$ & \\
\hline & $1.14(2)$ & $2.75(5)$ & 0.22 & $\mathrm{Fe}^{2+}$ & $6(1)$ & $\mathrm{Fe}_{2} \mathrm{P}_{2} \mathrm{O}_{7}$ \\
\hline & $1.07(3)$ & $2.16(6)$ & 0.20 & $\mathrm{Fe}^{2+}$ & $5(1)$ & \\
\hline
\end{tabular}

the notable absence of a peak at a $2 \theta=28^{\circ}$, indicating the absence of the $\beta$-phase under $\mathrm{H}_{2} \mathrm{O}$ oxidation also. This could be due to a high oxidizing atmosphere being required for the formation of $\beta$-phase and the low oxidizing strength of $\mathrm{H}_{2} \mathrm{O}$ compared to $\mathrm{O}_{2}{ }^{22,37}$
Mössbauer spectra of fresh, reduced (with $\mathrm{CH}_{4}$ ) and oxidized (with $\mathrm{N}_{2} \mathrm{O}, \mathrm{O}_{2}$ and $\mathrm{H}_{2} \mathrm{O}$ ) $\mathrm{FePO}_{4}$ catalysts are shown in Fig. 8. The spectra were corrected for thickness effects and then fitted with the analysis code RECOIL ${ }^{51}$ using Lorentzian line shapes for the spectral components. The spectral fit parameters (isomer shift

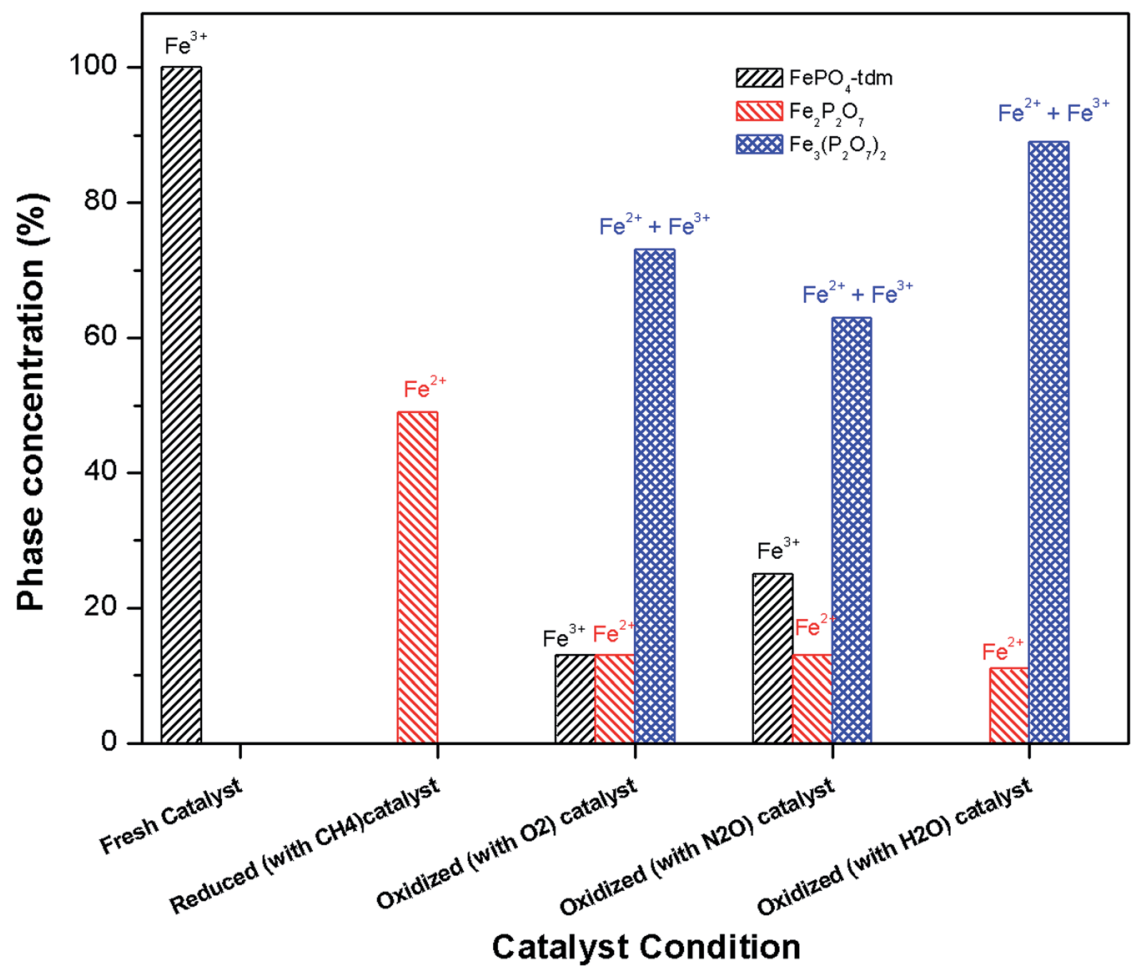

Fig. 9 Phase quantification of fresh, reduced (with $\mathrm{CH}_{4}$ ) and oxidized (with $\mathrm{N}_{2} \mathrm{O}, \mathrm{O}_{2}$ and $\mathrm{H}_{2} \mathrm{O}$ ) FePO catalyst determined from the Mössbauer spectra shown in Fig. 8. 
Table 3 Mössbauer parameters, isomer shift (IS), electric quadrupole splitting (QS), line width $\Gamma(H W H M)$ and the attributed phases of the spent catalyst after oxidation in $\mathrm{O}_{2}, \mathrm{~N}_{2} \mathrm{O}$ and $\mathrm{H}_{2} \mathrm{O}$ atmospheres ${ }^{a}$

\begin{tabular}{|c|c|c|c|c|c|c|}
\hline Oxidizing atmosphere & IS $\left(\mathrm{mm} \mathrm{s}^{-1}\right)$ & $\mathrm{QS}\left(\mathrm{mm} \mathrm{s}^{-1}\right)$ & $\begin{array}{l}\Gamma \\
(\mathrm{HWHM})\left(\mathrm{mm} \mathrm{s}^{-1}\right)\end{array}$ & Fe species & $\operatorname{Area}(\%)$ & Attributed phase \\
\hline \multirow[t]{4}{*}{$\mathrm{O}_{2}$} & $0.40(1)$ & $0.61(2)$ & 0.23 & $\mathrm{Fe}^{3+}$ & $51(2)$ & $\alpha-\mathrm{Fe}_{3}\left(\mathrm{P}_{2} \mathrm{O}_{7}\right)_{2}$ \\
\hline & $1.03(8)$ & $2.20(5)$ & 0.25 & $\mathrm{Fe}^{2+}$ & $7(1)$ & \multirow[t]{2}{*}{$\mathrm{Fe}_{2} \mathrm{P}_{2} \mathrm{O}_{7}$} \\
\hline & $1.11(4)$ & $2.74(4)$ & 0.18 & $\mathrm{Fe}^{2+}$ & $5(1)$ & \\
\hline & $0.29(1)$ & $0.21(2)$ & 0.14 & $\mathrm{Fe}^{3+}$ & $12(2)$ & $\mathrm{FePO}_{4}$-tdm \\
\hline & $1.19(4)$ & $2.00(5)$ & 0.15 & $\mathrm{Fe}^{2+}$ & $6(1)$ & \multirow[t]{3}{*}{$\mathrm{Fe}_{2} \mathrm{P}_{2} \mathrm{O}_{7}$} \\
\hline & $1.13(2)$ & $2.78(4)$ & 0.16 & $\mathrm{Fe}^{2+}$ & $6(1)$ & \\
\hline & $0.30(1)$ & $0.22(8)$ & 0.17 & $\mathrm{Fe}^{3+}$ & $26(1)$ & \\
\hline \multirow[t]{3}{*}{$\mathrm{H}_{2} \mathrm{O}$} & $0.30(1)$ & $0.65(5)$ & 0.22 & $\mathrm{Fe}^{3+}$ & $45(2)$ & \multirow{3}{*}{$\begin{array}{l}\alpha-\mathrm{Fe}_{3}\left(\mathrm{P}_{2} \mathrm{O}_{7}\right)_{2} \\
\alpha-\mathrm{Fe}_{3}\left(\mathrm{P}_{2} \mathrm{O}_{7}\right)_{2}\end{array}$} \\
\hline & $0.50(1)$ & $0.63(1)$ & 0.17 & $\mathrm{Fe}^{3+}$ & $26(1)$ & \\
\hline & $0.39(1)$ & $1.20(2)$ & 0.18 & $\mathrm{Fe}^{2+}$ & $17(2)$ & \\
\hline
\end{tabular}

(IS), electric quadrupole splitting (QS), line width (HWHM), area fractions $(f))$ and phase assignments are collected in Table 2 where the isomer shifts are given relative to $\alpha$-Fe at room temperature. The phase assignments were made on the basis of parameters reported in ref. 36,37 and $40-42$.

The phase parameters of the fresh catalyst confirm that only the $\mathrm{FePO}_{4}$-tdm phase is present in the catalyst, in agreement with literature and previous work. ${ }^{23,24,37}$ Two $\mathrm{Fe}^{2+}$ species which are observed after the reduction of the fresh catalyst under methane at $500{ }^{\circ} \mathrm{C}$, are attributable to the $\mathrm{Fe}_{2} \mathrm{P}_{2} \mathrm{O}_{7}$ phase. ${ }^{22} \mathrm{~A}$ $17 \%$ contribution from a $\mathrm{FePO}_{4}$ low quartz phase is evident, most likely the result of the unreduced phase present in the catalyst. ${ }^{37}$ The effect of oxygen atmosphere on the phase formation is reflected by the Mössbauer spectrum for the $\mathrm{O}_{2}$ oxidized catalyst (Fig. 8), which shows a $74 \%$ spectral area due to a $\mathrm{Fe}^{3+}$ iron phase and a weaker $\mathrm{Fe}^{2+}$ component with IS of $1.15 \mathrm{~mm} \mathrm{~s}^{-1}$ and $\mathrm{QS}$ of $2.71 \mathrm{~mm} \mathrm{~s}^{-1}$. These values are in accordance with the values of $\mathrm{Fe}^{3+}$ and $\mathrm{Fe}^{2+}$ components in the $\alpha$-phase of the catalyst, $\alpha$ - $\mathrm{Fe}_{3}\left(\mathrm{P}_{2} \mathrm{O}_{7}\right)_{2}$. The XRD profile of the catalyst also supports this assignment. In addition, a trydimite like $\mathrm{FePO}_{4}$ phase is observed with a spectral area of $13 \%$.

The Mössbauer spectrum obtained for the oxidized catalyst with $\mathrm{N}_{2} \mathrm{O}$ (Fig. 8), showed a $12 \%$ contribution from components with IS and QS values characteristic of $\mathrm{Fe}^{2+}$ (Fig. 9 and Table 2) which can be assigned to the $\mathrm{Fe}_{2} \mathrm{P}_{2} \mathrm{O}_{7}$ phase. In addition, the spectrum showed a $18 \% \mathrm{Fe}^{3+}$ component with parameters corresponding to the $\alpha$-phase together with a mixture of $44 \% \mathrm{Fe}^{2+}$ in the $\mathrm{Fe}_{2} \mathrm{P}_{2} \mathrm{O}_{7}$ phase. $\mathrm{A} \mathrm{Fe}^{3+}$ species, with IS and QS values which were not characteristic of a typical $\mathrm{FePO}_{4}$-tdm phase in the oxidized catalyst, with a $26 \%$ site fraction is observed. ${ }^{22,37}$ The Mössbauer spectrum of the catalyst oxidized with $\mathrm{H}_{2} \mathrm{O}$, showed $\mathrm{Fe}^{2+}$ components with a combined $11 \%$ intensity, which can be assigned to the $\mathrm{Fe}_{2} \mathrm{P}_{2} \mathrm{O}_{7}$ phase. The spectrum also shows the presence of the $\mathrm{Fe}^{3+}$ species with a $88 \%$ site fraction (Fig. 10). The respective IS and QS values of this ferric species are in agreement with the $\mathrm{Fe}^{3+}$ species in the various iron phosphate type phases, namely the $\alpha$-phase. ${ }^{20,22,23}$

In the Powder XRD diffractogram of the used catalyst after the reaction with $\mathrm{O}_{2}$ atmosphere, two major peaks are evident at

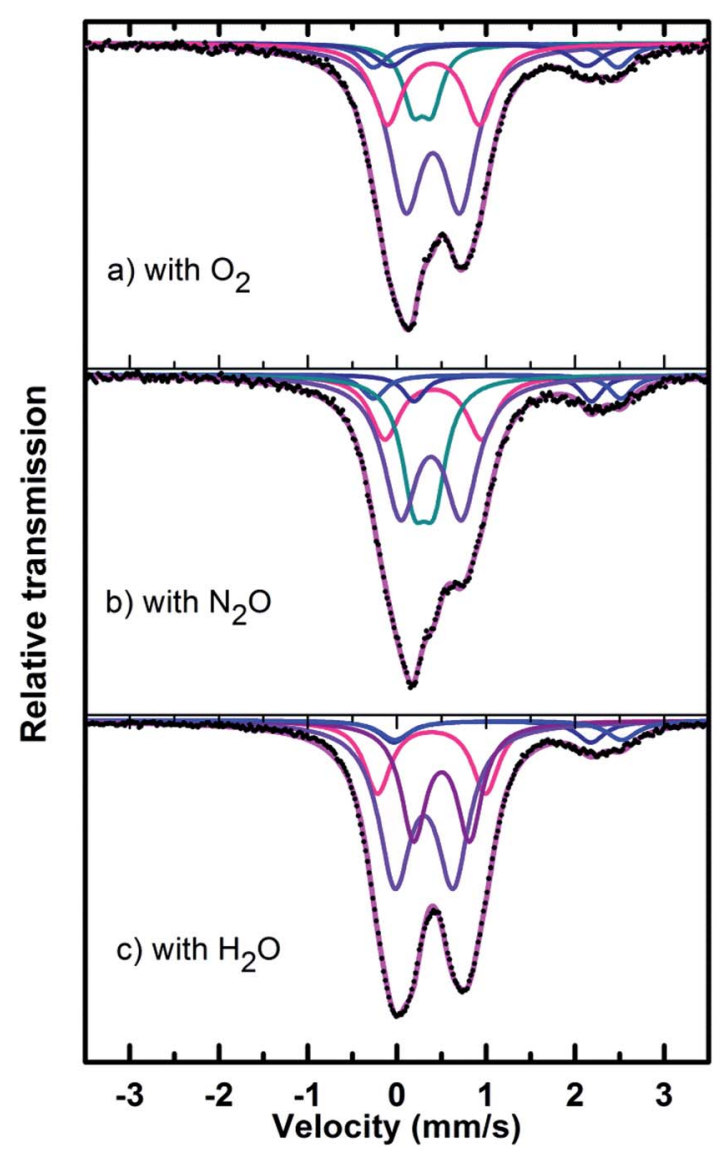

Fig. 10 Mössbauer spectra of used catalysts after reaction with (a) $\mathrm{O}_{2}$, (b) $\mathrm{N}_{2} \mathrm{O}$ and (c) $\mathrm{H}_{2} \mathrm{O}$. 


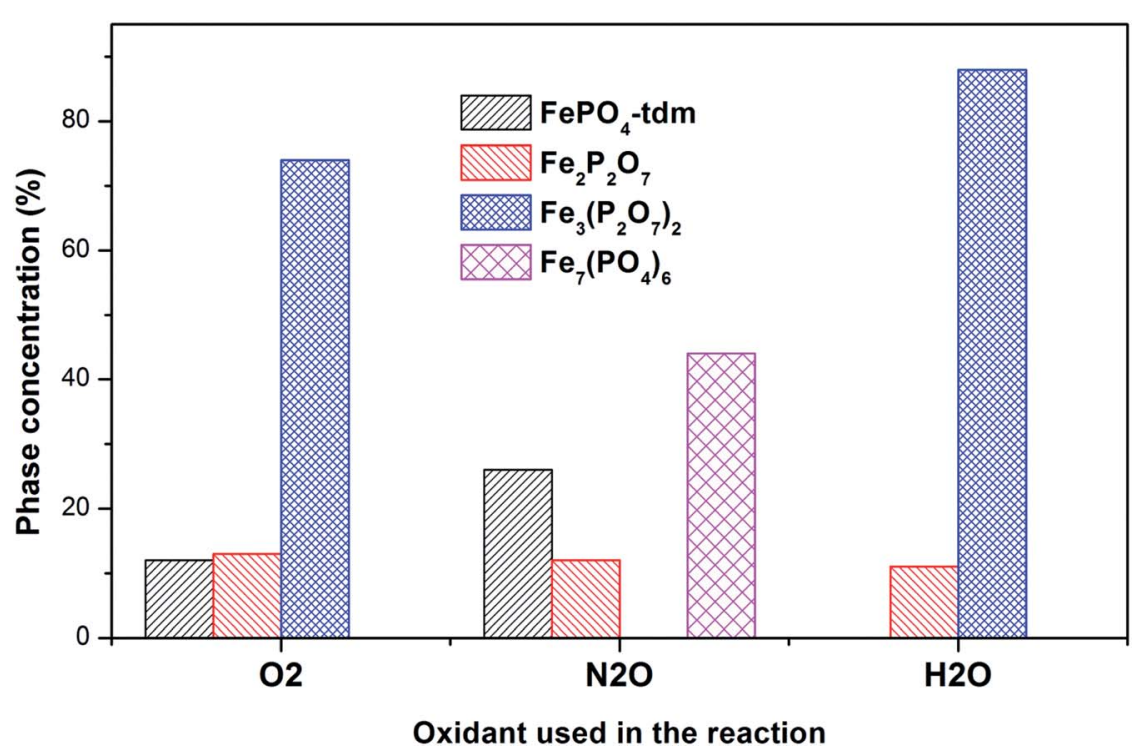

Fig. 11 Phase quantification of used catalysts after reaction with $\mathrm{O}_{2}, \mathrm{~N}_{2} \mathrm{O}$ and $\mathrm{H}_{2} \mathrm{O}$, determined from the Mössbauer spectra.

$34.2^{\circ}$ and $35.1^{\circ}$ which can be attributed to the $\mathrm{Fe}_{2} \mathrm{P}_{2} \mathrm{O}_{7}$ phase, but this region also coincides with an overlap of the most intense peak of the $\alpha$-phase. ${ }^{20,37}$ In the Mössbauer data of the used catalysts (Fig. 10), the $\alpha-\mathrm{Fe}_{3}\left(\mathrm{P}_{2} \mathrm{O}_{7}\right)_{2}$ phase, with a $\mathrm{Fe}^{3+}$ spectral component, was the dominant phase (74\%). The appearance of the $\mathrm{Fe}_{2} \mathrm{P}_{2} \mathrm{O}_{7}$ phase was also observed, with ferric and ferrous species each contributing towards an $11 \%$ total site fraction. ${ }^{43}$ The formation of the $\alpha$-phase results from the transformation between the $\mathrm{FePO}_{4}$-tdm and $\mathrm{Fe}_{2} \mathrm{P}_{2} \mathrm{O}_{7}$ phases, which takes place reversibly, depending on strength of the redox atmosphere $e^{20,23}$ and the fact that the $\alpha-\mathrm{Fe}_{3}\left(\mathrm{P}_{2} \mathrm{O}_{7}\right)_{2}$ phase is a mixed ferric and ferrous pyrophosphate consisting of both $\mathrm{Fe}_{4}\left(\mathrm{P}_{2} \mathrm{O}_{7}\right)_{3}$ and $\mathrm{Fe}_{2} \mathrm{P}_{2} \mathrm{O}_{7}{ }^{37,43}$

The diffractogram obtained for the used catalyst after the reaction with $\mathrm{N}_{2} \mathrm{O}$ (ESI, Fig. S5 $\dagger$ ), showed an intense, sharp peak at $2 \theta=34.5^{\circ}$. The Mössbauer data (Fig. 10) for the used catalyst after the reaction with $\mathrm{N}_{2} \mathrm{O}$ showed typical of $\mathrm{Fe}^{3+}$ species $(88 \%)$ and $\mathrm{Fe}^{2+}$ species $(12 \%)$ with parameters which correlate with the $\mathrm{FePO}_{4}$-low quartz and $\mathrm{Fe}_{7}\left(\mathrm{PO}_{4}\right)_{6}$ phases. In addition, there is a component (22\%) with IS and QS values corresponding to $\mathrm{Fe}^{2+}$ which we identified as $\mathrm{Fe}_{2} \mathrm{P}_{2} \mathrm{O}_{7}$ phase. These results showed an enhancement towards the $\alpha$-phase after reaction with $\mathrm{N}_{2} \mathrm{O}$ atmosphere. The absence of the $\beta$-phase during the oxidation reactions has been observed in previous studies, especially during the oxidative dehydrogenation of isobutyric acid with a water co-feed over $\mathrm{FePO}_{4}$ catalyst. ${ }^{2,23,43}$ In literature, it has been reported that an $\mathrm{FePO}_{4}$ catalyst consisting of the quartz type phase as the precursor, undergoes phase transformation during a catalytic reaction involving the oxidative dehydrogenation of isobutyric acid to form $\mathrm{Fe}_{7}\left(\mathrm{PO}_{4}\right)_{6}$ and the $\alpha$-phase (Table 3). ${ }^{\mathbf{1 8 , 2 3}}$

The diffractogram of the used catalyst using $\mathrm{H}_{2} \mathrm{O}$ as an oxidant showed the presence of $\mathrm{Fe}_{2} \mathrm{P}_{2} \mathrm{O}_{7}$ phase along with $\alpha$ phase. The Mössbauer spectrum, after using $\mathrm{H}_{2} \mathrm{O}$ as an oxidant (Fig. 10), showed $\mathrm{Fe}^{2+}$ and $\mathrm{Fe}^{3+}$ components with a relative intensities of $11 \%$ and $71 \%$ (Fig. 11), which can be assigned to the $\alpha-\mathrm{Fe}_{3}\left(\mathrm{P}_{2} \mathrm{O}_{7}\right)_{2}$ phase..$^{\mathbf{2 0 2 2 , 2 3}}$ Similar to the catalyst obtained after reaction under $\mathrm{N}_{2} \mathrm{O}$ atmosphere, no evidence of $\beta$-phase was observed after the reaction with $\mathrm{H}_{2} \mathrm{O}$ also. ${ }^{17,18,24}$ It has been reported that formation of the $\beta$-phase is dependent on the catalyst structure and redox atmosphere. ${ }^{\mathbf{4 3 4 4}}$ Obviously, water plays a role in avoiding high reduction atmospheres. Similar observation was reported in literature, ${ }^{22,37}$ that the addition of the water co-feed in the reaction, blocks the formation of the less selective $\beta$-phase. In summary, the XRD and Mössbauer spectra of the fresh and used catalysts oxidized in the presence of $\mathrm{N}_{2} \mathrm{O}$ and $\mathrm{H}_{2} \mathrm{O}$ showed that the $\alpha$-phase was formed in high quantity ${ }^{22}$ when the formation of $\beta$-phase was suppressed.

Panov et $a .^{3,12}$ assessed the methane partial oxidation by nitrous oxide in the processes in which the $\alpha$-oxygen sites were created at $160{ }^{\circ} \mathrm{C}$ temperature over FeZSM-5 zeolite. They discovered that the reactions occur through a hydrogen abstraction mechanism, making methoxy or hydroxy groups bounded to the $\alpha$-sites. When the same reaction is performed with heating to $160{ }^{\circ} \mathrm{C}$, they verified that at $\mathrm{CH}_{4}: \mathrm{N}_{2} \mathrm{O}$ molar ratio equal to $1: 1$, the reactions directly provide methanol. Wood et al. studied the mechanism of "catalytic" oxidation reactions of methane by nitrous oxide over Fe-ZSM-5 zeolite, and concluded that the primary products of methane oxidation are methoxy groups bounded to active iron (i.e., $\mathrm{Fe}-\mathrm{OCH}_{3}$ ). As can be seen, the $\mathrm{Fe}^{2+}$ cations of $\alpha$-sites are activated by nitrous oxide generating adsorbed oxidant species (i.e., $\left.\mathrm{Fe}^{3+}-\mathrm{O}^{\cdot}-\right)_{\alpha^{-}}$ sites, which convert methane to adsorbed methanol. Afterwards, adsorbed methanol can be converted to dimethyl ether and water. Beznis et al. ${ }^{45}$ assessed the activity of Co-ZSM-5 solid catalysts on reactions of partial oxidation of methane. They found that methanol production proportionally increased in relation to surface area of catalyst, which can be increased treating the catalyst with $\mathrm{NaOH}$. These authors discovered that the active sites (i.e., cobalt oxidic species, such as $\mathrm{Co}_{3} \mathrm{O}_{4}$ and 
Table 4 Comparison of catalytic performance of Fe based catalysts for methane activation reaction reported in literature

\begin{tabular}{|c|c|c|c|c|c|}
\hline S. no & Catalyst & Oxidant & $\begin{array}{l}\text { Temperature } \\
\left({ }^{\circ} \mathrm{C}\right)\end{array}$ & Methanol TOF $\left(\mu \mathrm{mol}_{\mathrm{MeOH}} \mathrm{g}_{\mathrm{cat}} \mathrm{h}^{-1}\right)$ & Reference \\
\hline 1 & 2\% Fe-ZSM5 & $\mathrm{O}_{2}$ & 300 & $6.3 \times 10^{-4}$ & 4 \\
\hline 3 & $2 \% \mathrm{Fe}-\mathrm{ZSM} 5$ & $\mathrm{~N}_{2} \mathrm{O}$ & 550 & $7.1 \times 10^{-3}$ & 19 \\
\hline 4 & $0.5 \%$ Fe-SIL-1 & $\mathrm{N}_{2} \mathrm{O}$ & 550 & $8 \times 10^{-3}$ & 2 \\
\hline 5 & $\mathrm{FePO}_{4} / \mathrm{MCM}-41$ & $\mathrm{O}_{2}$ & 400 & $7.5 \times 10^{-4}$ & 14 \\
\hline 8 & $0.5 \% \mathrm{Fe}-\mathrm{SiO}_{2}$ & $\mathrm{O}_{2}$ & 500 & $2.1 \times 10^{-4}$ & 49 and 50 \\
\hline 9 & $\mathrm{FePO}_{4}-\mathrm{tdm}$ & $\mathrm{O}_{2}$ & 300 & $5.3 \times 10^{-3}$ & This work \\
\hline 10 & $\mathrm{FePO}_{4}$-tdm & $\mathrm{N}_{2} \mathrm{O}$ & 300 & $12.3 \times 10^{-3}$ & This work \\
\hline
\end{tabular}

$\mathrm{CoO}$, present on catalyst external surface) were also proportionally formed in relation to surface area of solid catalyst. In the presence of $\mathrm{N}_{2} \mathrm{O}, \mathrm{CH}_{4}$ would be oxidized by peroxo species $\mathrm{MO}_{2}$ formed by the reaction of $\mathrm{N}_{2} \mathrm{O}$ with a $\mathrm{Fe}=\mathrm{O}$ centre. $\mathrm{Fe}=\mathrm{O}$ centres may be the active sites for methanol formation., ${ }^{3,17,46}$ The kinetic results obtained on the oxidation of $\mathrm{CH}_{4}$ by $\mathrm{N}_{2} \mathrm{O}$ showed that carbon oxides are probably primary products and may also stem from methanol or formaldehyde as secondary products. The direct pathway to carbon oxides could be ascribed to the existence of surface sites where the intermediate oxygenates expected are strongly attached and not allowed to desorb in the gas phase. In contrast, formation of methanol or formaldehyde would rather correspond to oxygenate precursors more easily desorbed because less retained at the catalyst surface.

In literature, it is well established that $\mathrm{Fe}$ based catalysts entail different chemical properties considering those of their other individual monometallic components, e.g. achieving the synergistic effects in methane activation reactions. In general, ZSM-5 catalysts show a higher activity for methane activation than other supports. Panov and co-workers ${ }^{3,4}$ showed the methane oxidation over Fe-ZSM- 5 catalysts by $\mathrm{N}_{2} \mathrm{O}$ at $200^{\circ} \mathrm{C}$ and showed that methanol that formed via methane oxidation by $\alpha$ oxygen, $\mathrm{CH}_{4}+\left(\mathrm{Fe}^{\mathrm{III}}-\mathrm{O}^{--}\right) \alpha$, migrated from $\alpha$-sites, initiating new reaction cycles. At $200{ }^{\circ} \mathrm{C}$, a $4 \mathrm{~h}$ run provided a turn over frequency (TOF) of $5.5 \times 10^{-3} \mu \mathrm{mol}_{\mathrm{MeOH}} \mathrm{g}_{\text {cat }} \mathrm{h}^{-1}$. Beznis and coworkers $^{45,47}$ showed that the selective activation of methane towards methanol over Co-ZSM- 5 can be influenced by altering the micro-and meso-porosity of the zeolite material. They showed a linear relationship between the ZSM-5 surface area and the amount of methanol produced $\left(5.5 \times 10^{-3} \mu \mathrm{mol}_{\mathrm{MeOH}}\right.$ $\mathrm{g}_{\mathrm{cat}} \mathrm{h}^{-1}$ ) over Co-ZSM-5 from methane and oxygen at $250{ }^{\circ} \mathrm{C}$ (Table 4).

Zhang and co-workers ${ }^{48-50}$ showed that the iron species introduced into mesoporous silica SBA- 15 could catalyze the selective oxidation of $\mathrm{CH}_{4}$ to methanol by $\mathrm{O}_{2}$ and that the catalyst with a Fe content of $0.5 \mathrm{wt} \%$ provided the highest single-pass yield $\left(2.1 \times 10^{-4} \mu \mathrm{mol}_{\mathrm{MeOH}} \mathrm{g}_{\text {cat }} \mathrm{h}^{-1}\right)$. The TOF towards methanol formation decreased with increasing $\mathrm{Fe}$ content. They also studied SBA-15-supported iron phosphate $\left(\mathrm{FePO}_{4}\right)$ for the partial oxidation of $\mathrm{CH}_{4}$ with $\mathrm{O}_{2}$. The SBA-15supported $\mathrm{FePO}_{4}$ catalysts exhibit higher $\mathrm{CH}_{4}$ conversion and
$\mathrm{MeOH}$ selectivity than the unsupported and the MCM-41supported ones in the partial oxidation of $\mathrm{CH}_{4}$ with $\mathrm{O}_{2}{ }^{14,48,50}$ The catalyst with a loading amount of $5 \mathrm{wt} \%$ shows the highest $\mathrm{MeOH}$ selectivity at a given $\mathrm{CH}_{4}$ conversion and the highest $\mathrm{MeOH}$ formation rate based on the amount of $\mathrm{FePO}_{4}$ in the catalyst. It is likely that the improved catalytic performances of the SBA-15-supported samples are related to the enhanced redox properties of $\mathrm{FePO}_{4}$ species, the large porous diameter and the high inertness of SBA- $15 .{ }^{48}$ With compared to the other catalysts reported in literature, the $\mathrm{FePO}_{4}$-tdm phase catalysts showed in this work exhibited a high activity towards methanol i.e., $12.3 \times 10^{-3} \mu \mathrm{mol}_{\mathrm{MeOH}} \mathrm{g}_{\text {cat }} \mathrm{h}^{-1}$ using $\mathrm{N}_{2} \mathrm{O}$ as an oxidant. This catalyst also showed a high activity with $\mathrm{O}_{2}$ as an oxidant $\left(5.3 \times 10^{-3} \mu \mathrm{mol}_{\mathrm{MeOH}} \mathrm{g}_{\mathrm{cat}} \mathrm{h}^{-1}\right)$.

\section{Conclusion}

A high yield of methanol was observed over $\mathrm{FePO}_{4}$ when using $\mathrm{N}_{2} \mathrm{O}$ as oxidant. The methane conversion with $\mathrm{O}_{2}$ and $\mathrm{N}_{2} \mathrm{O}$ increased steeply with temperature but increased much slower when $\mathrm{H}_{2} \mathrm{O}$ was applied as an oxidizing agent. Furthermore, the maximum $\mathrm{CH}_{4}$ consumption (17 mol\%) was obtained when oxygen had been used as the oxidant at $500{ }^{\circ} \mathrm{C}$, the highest in this study. The selectivity towards methanol was very good at lower methane conversions (elevated flow rates). Additionally, when a comparison was made at all the levels of $\mathrm{CH}_{4}$ consumption, it was the highest when $\mathrm{N}_{2} \mathrm{O}$ was used as an oxidant. The present results clearly show that the selective oxidation of methane over $\mathrm{FePO}_{4}$ is influenced by the nature of the oxidizing agent. Furthermore, the fresh catalyst possessed a rough crystalline morphology with particle sizes ranging from 50 to $80 \mathrm{~nm}$, and with a homogeneous dispersion of crystallites. After reduction, agglomeration of these nanoparticles was observed. After the oxidation with $\mathrm{O}_{2}$, the crystalline nature was retained, but with separate agglomerated bulk particles present. From TPRO profiles, it was evident that the type of oxidant, used in re-oxidation, influenced the pathway of oxidation for a reduced $\mathrm{FePO}_{4}$ catalyst.

Mössbauer spectroscopy, complemented with powder X-ray diffraction, proved to be a very sensitive tool in providing an understanding of the phase transformations of $\mathrm{FePO}_{4}$ material 
using $\mathrm{O}_{2}, \mathrm{H}_{2} \mathrm{O}$ and $\mathrm{N}_{2} \mathrm{O}$ as oxidizing agents for the selective conversion of methane to methanol. The Mössbauer data provided evidence that the $\mathrm{Fe}_{2} \mathrm{P}_{2} \mathrm{O}_{7}$ phase was dominant in the reduced catalyst sample, while its amount decreased five-fold after the oxidation with $\mathrm{O}_{2}$ due to the formation of $\alpha$ domains. In the Mössbauer data of the used catalysts, the $\alpha$ $\mathrm{Fe}_{3}\left(\mathrm{P}_{2} \mathrm{O}_{7}\right)_{2}$ phase, with a $\mathrm{Fe}^{3+}$ spectral component, was the dominant phase $(74 \%)$. The appearance of the $\mathrm{Fe}_{2} \mathrm{P}_{2} \mathrm{O}_{7}$ phase was also observed, with ferric and ferrous species each contributing towards an $11 \%$ total site fraction. The formation of the $\alpha$-phase results from the transformation between the $\mathrm{FePO}_{4}$-tdm and $\mathrm{Fe}_{2} \mathrm{P}_{2} \mathrm{O}_{7}$ phases, which takes place reversibly, depending on strength of the redox atmosphere and the fact that the $\alpha-\mathrm{Fe}_{3}\left(\mathrm{P}_{2} \mathrm{O}_{7}\right)_{2}$ phase is a mixed ferric and ferrous pyrophosphate consisting of both $\mathrm{Fe}_{4}\left(\mathrm{P}_{2} \mathrm{O}_{7}\right)_{3}$ and $\mathrm{Fe}_{2} \mathrm{P}_{2} \mathrm{O}_{7}$. In summary, the XRD and Mössbauer spectra of the fresh and used catalysts oxidized in the presence of $\mathrm{N}_{2} \mathrm{O}$ and $\mathrm{H}_{2} \mathrm{O}$ showed that the $\alpha$-phase was formed in high quantity when the formation of $\beta$-phase was suppressed. When compared to the other catalysts reported in literature, the $\mathrm{FePO}_{4}$-tdm phase catalysts showed in this work exhibited a high activity towards methanol i.e., $12.3 \times$ $10^{-3} \mu \mathrm{mol}_{\mathrm{MeOH}} \mathrm{g}_{\text {cat }} \mathrm{h}^{-1}$ using $\mathrm{N}_{2} \mathrm{O}$ as an oxidant. This catalyst also showed a high activity with $\mathrm{O}_{2}$ as an oxidant $\left(5.3 \times 10^{-3}\right.$ $\mu \mathrm{mol}_{\mathrm{MeOH}} \mathrm{g}_{\text {cat }} \mathrm{h}^{-1}$ ).

\section{Conflicts of interest}

There are no conflicts to declare.

\section{Acknowledgements}

The authors acknowledge the financial support from the Slovenian Research Agency (research core funding No. P2-0152 and P1-0112) within the project Direct Conversion of Methane to Higher Hydrocarbons using Superacid Catalysts, J2-7319. KB-R acknowledges support from the National Research Foundation (South Africa).

\section{References}

1 K. Otsuka and Y. Wang, Appl. Catal., A, 2001, 222, 145-161. 2 M. C. Alvarez-Galvan, N. Mota, M. Ojeda, S. Rojas, R. M. Navarro and J. L. G. Fierro, Catal. Today, 2011, 171, 15-23.

3 E. V. Starokon, M. V. Parfenov, S. S. Arzumanov, L. V. Pirutko, A. G. Stepanov and G. I. Panov, J. Catal., 2013, 300, 47-54.

4 M. V. Parfenov, E. V. Starokon, L. V. Pirutko and G. I. Panov, J. Catal., 2014, 318, 14-21.

5 A. A. Latimer, A. Kakekhani, A. R. Kulkarni and J. K. Nørskov, ACS Catal., 2018, 8, 6894-6907.

6 A. S. Rosen, J. M. Notestein and R. Q. Snurr, ACS Catal., 2019, 9, 3576-3587.

7 J. Bao, G. Yang, Y. Yoneyama and N. Tsubaki, ACS Catal., 2019, 9, 3026-3053.

8 P. Khirsariya and R. K. Mewada, Procedia Eng., 2013, 51, 409415.
9 C. Hammond, N. Dimitratos, R. L. Jenkins, J. A. LopezSanchez, S. A. Kondrat, M. Hasbi ab Rahim, M. M. Forde, A. Thetford, S. H. Taylor, H. Hagen, E. E. Stangland, J. H. Kang, J. M. Moulijn, D. J. Willock and G. J. Hutchings, ACS Catal., 2013, 3, 689-699.

10 Y. Wang and K. Otsuka, J. Mol. Catal. A: Chem., 1996, 111, 341-356.

11 T. Sheppard, C. D. Hamill, A. Goguet, D. W. Rooney and J. M. Thompson, Chem. Commun., 2014, 50, 11053-11055.

12 G. I. Panov, K. A. Dubkov and A. S. Kharitonov, in Modern Heterogeneous Oxidation Catalysis, Wiley-VCH Verlag GmbH \& Co. KGaA, 2009, ch. 7, pp. 217-252, DOI: 10.1002/ 9783527627547.

13 Y. Wang, W. Yang, L. Yang, X. Wang and Q. Zhang, Catal. Today, 2006, 117, 156-162.

14 X. Wang, Y. Wang, Q. Tang, Q. Guo, Q. Zhang and H. Wan, J. Catal., 2003, 217, 457-467.

15 Y. Shiota and K. Yoshizawa, J. Am. Chem. Soc., 2000, 122, 12317-12326.

16 R. B. Anderson, K. C. Stein, J. J. Feenan and L. J. E. Hofer, Ind. Eng. Chem., 1961, 53, 809-812.

17 R. Polnišer, M. Štolcová, M. Hronec and M. Mikula, Appl. Catal., A, 2011, 400, 122-130.

18 M. Štolcová, C. Litterscheid, M. Hronec and R. Glaum, in Studies in Surface Science and Catalysis, ed. M. S. Fábio Bellot Noronha and S.-A. Eduardo Falabella, Elsevier, 2007, vol. 167, pp. 37-42.

19 C. Kalamaras, D. Palomas, R. Bos, A. Horton, M. Crimmin and K. Hellgardt, Catal. Lett., 2016, 146, 483-492.

20 R. L. McCormick, G. O. Alptekin, D. L. Williamson and T. R. Ohno, Top. Catal., 2000, 10, 115-122.

21 J. Schumann, A. Tarasov, N. Thomas, R. Schlögl and M. Behrens, Appl. Catal., A, 2016, 516, 117-126.

22 F. B. Khan, K. Bharuth-Ram and H. B. Friedrich, Hyperfine Interact., 2010, 197, 317-323.

23 F. B. Khan, V. D. B. C. Dasireddy, K. Bharuth-Ram, H. Masenda and H. B. Friedrich, Hyperfine Interact., 2015, 231, 123-129.

24 V. D. B. C. Dasireddy, K. Bharuth-Ram, A. Harilal, S. Singh and H. B. Friedrich, Hyperfine Interact., 2015, 231, 137-142.

25 V. D. B. C. Dasireddy, S. Singh and H. B. Friedrich, Appl. Catal., A, 2013, 456, 105-117.

26 T. Chetty, H. B. Friedrich, V. D. B. C. Dasireddy, A. Govender, P. J. Mohlala and W. Barnard, ChemCatChem, 2014, 6, 23842393.

27 V. D. B. C. Dasireddy and B. Likozar, Energy Technol., 2017, 5, 1344-1355.

28 Š. Hajduk, V. D. B. C. Dasireddy, B. Likozar, G. Dražić and Z. C. Orel, Appl. Catal., B, 2017, 211, 57-67.

29 J. H. Lunsford, Catal. Today, 2000, 63, 165-174.

30 A. V. Annapragada and E. Gulari, J. Catal., 1990, 123, 130146.

31 J. Zhang, H. Wang and A. K. Dalai, J. Catal., 2007, 249, 300310.

32 H. Du, H. Zhu, T. Liu, Z. Zhao, X. Chen, W. Dong, W. Lu, W. Luo and Y. Ding, Catal. Today, 2017, 281, 549-558. 
33 H. G. Merkus, Particle Size Measurements: Fundamentals, Practice, Quality, Springer Netherlands, 2009.

34 F. Khan, V. B. C. Dasireddy, K. Bharuth-Ram, H. Masenda and H. B. Friedrich, Hyperfine Interact., 2015, 231, 123-129.

35 J. M. M. Millet and J. C. Vedrine, Appl. Catal., 1991, 76, 209219.

36 J. M. Millet, C. Virely, M. Forissier, P. Bussière and J. C. Vedrine, Hyperfine Interact., 1989, 46, 619-628.

37 J.-M. M. Millet, Catal. Rev., 1998, 40, 1-38.

38 P. Bonnet and J. M. M. Millet, J. Catal., 1996, 161, 198-205.

39 E. Muneyama, A. Kunishige, K. Ohdan and M. Ai, Bull. Chem. Soc. Jpn., 1996, 69, 509-513.

40 P. Bonnet, J. M. M. Millet, C. Leclercq and J. C. Védrine, J. Catal., 1996, 158, 128-141.

41 J. C. Vedrine, J. M. M. Millet and J.-C. Volta, Catal. Today, 1996, 32, 115-123.

42 J.-M. Millet and J. Védrine, Top. Catal., 2001, 15, 139-144.

$43 \mathrm{M}$. Ai and K. Ohdan, in Studies in Surface Science and Catalysis, ed. F. V. M. S. M. Avelino Corma and G. F.José Luis, Elsevier, 2000, vol. 130, pp. 755-760.
44 M. Ai and K. Ohdan, in Studies in Surface Science and Catalysis, ed. S. T. O. A. M. G. R. K. Grasselli and J. E.Lyons, Elsevier, 1997, vol. 110, pp. 527-534.

45 N. V. Beznis, B. M. Weckhuysen and J. H. Bitter, Catal. Lett., 2010, 136, 52-56.

46 T. Ren, L. Yan, X. Zhang and J. Suo, Appl. Catal., A, 2003, 244, 11-17.

47 N. V. Beznis, A. N. C. van Laak, B. M. Weckhuysen and J. H. Bitter, Microporous Mesoporous Mater., 2011, 138, 176183.

48 Y. Wang, X. Wang, Z. Su, Q. Guo, Q. Tang, Q. Zhang and H. Wan, Catal. Today, 2004, 93-95, 155-161.

49 J. He, Y. Li, D. An, Q. Zhang and Y. Wang, J. Nat. Gas Chem., 2009, 18, 288-294.

50 Q. Zhang, Y. Li, D. An and Y. Wang, Appl. Catal., A, 2009, 356, 103-111.

51 K. Lagarec and D. G. Rancourt, Recoil-Mössbauer spectral analysis software for Windows, version 1.0, Department of Physics, University of Ottawa, Ottawa, ON, Canada, 1998, pp. 43. 